San Jose State University

SJSU ScholarWorks

Master's Theses

Master's Theses and Graduate Research

1999

\title{
Chemical, physical, and sensory characteristics of spray dried banana powder
}

Laura Ann Hawkins

San Jose State University

Follow this and additional works at: https://scholarworks.sjsu.edu/etd_theses

\section{Recommended Citation}

Hawkins, Laura Ann, "Chemical, physical, and sensory characteristics of spray dried banana powder" (1999). Master's Theses. 1817.

DOI: https://doi.org/10.31979/etd.x6q6-z9v4

https://scholarworks.sjsu.edu/etd_theses/1817

This Thesis is brought to you for free and open access by the Master's Theses and Graduate Research at SJSU ScholarWorks. It has been accepted for inclusion in Master's Theses by an authorized administrator of SJSU ScholarWorks. For more information, please contact scholarworks@sjsu.edu. 


\section{INFORMATION TO USERS}

This manuscript has been reproduced from the microfilm master. UMI films the text directly from the original or copy submitted. Thus, some thesis and dissertation copies are in typewriter face, while others may be from any type of computer printer.

The quality of this reproduction is dependent upon the quality of the copy submitted. Broken or indistinct print, colored or poor quality illustrations and photographs, print bleedthrough, substandard margins, and improper alignment can adversely affect reproduction.

In the unlikely event that the author did not send UMI a complete manuscript and there are missing pages, these will be noted. Also, if unauthorized copyright material had to be removed, a note will indicate the deletion.

Oversize materials (e.g., maps, drawings, charts) are reproduced by sectioning the original, beginning at the upper left-hand corner and continuing from left to right in equal sections with small overlaps. Each original is also photographed in one exposure and is included in reduced form at the back of the book.

Photographs included in the original manuscript have been reproduced xerographically in this copy. Higher quality $6 " \times 9 "$ black and white photographic prints are available for any photographs or illustrations appearing in this copy for an additional charge. Contact UMI directly to order.

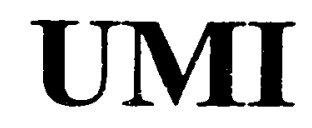

A Bell \& Howell Information Company 300 North Zeeb Road, Ann Arbor MI 48106-1346 USA

$313 / 761-4700 \quad 800 / 521-0600$ 



\title{
CHEMICAL, PHYSICAL, AND SENSORY CHARACTERISTICS OF SPRAY DRIED BANANA POWDER
}

\author{
A Thesis \\ Presented to \\ San Jose State University \\ In Partial Fulfillment \\ of the Requirements for the Degree \\ Master of Science \\ in Nutritional Science
}

The Faculty of the Department of Nutrition and Food Science

by

Laura Ann Hawkins

May 1999 
UMI Number: 1394529

UMI Microform 1394529

Copyright 1999, by UMI Company. All rights reserved.

This microform edition is protected against unauthorized copying under Title 17, United States Code.

\section{UMI}

300 North Zeeb Road

Ann Arbor, MI 48103 
(C) 1999

Laura Ann Hawkins

ALL RIGHTS RESERVED 
APPROVED FOR THE DEPARTMENT OF NUTRITION AND FOOD SCIENCE
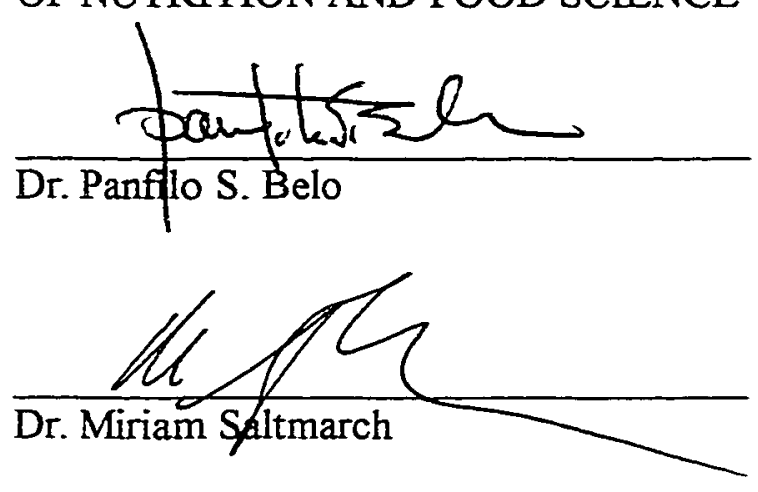

$\frac{\operatorname{ling} \text { he found }}{\text { Dr. Lucy McProud }}$

APPROVED FOR THE UNIVERSITY

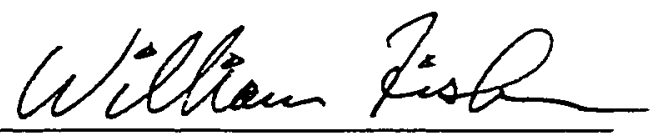




\section{ABSTRACT \\ CHEMICAL, PHYSICAL, AND SENSORY CHARACTERISTICS \\ OF SPRAY DRIED BANANA POWDER}

by Laura Ann Hawkins

The objective of this study was to determine the chemical, physical, and sensory characteristics of spray dried banana powder produced under laboratory scale conditions. Banana puree containing $8.9 \%$ maltodextrin was spray dried in a co-current flow vertical type of spray dryer. Yield, proximate composition, potassium content, water activity, bulk density, dispersibility, and sensory quality of the resulting powder were determined and compared with that of dehydrated banana powder prepared from cabinet convection dried bananas.

Spray dried banana powder has a moderate potassium content, is low in fat and protein and high in carbohydrates. The spray dried powder has a bulk density similar to other food powders $\left(0.3\right.$ to $\left.0.8 \mathrm{~g} / \mathrm{cm}^{3}\right)$. A sensory evaluation revealed that the taste of spray dried banana most closely matched fresh banana while its odor and texture did not. Overall acceptability was influenced most by odor and texture, rather than color and taste. 


\section{ACKNOWLEDGMENT}

I would like to acknowledge Dr. Panfilo S. Belo, my graduate advisor, for his expert advice and never ending support throughout this research. His direction, motivation, and patience contributed deeply to the completion of this study. I would like to thank Dr. Miriam Saltmarch for her expertise, advice, friendship, and encouragement she has given me during the past two and a half years. I would also like to thank Dr. Lucy McProud for her knowledge and input as a member of my graduate committee. Finally, and very importantly, I would like to thank my husband, sons, and parents for their interest, encouragement, support, and patience throughout my graduate studies at San Jose State University. 


\section{PREFACE}

The following thesis is written in publication style. The second chapter is written in journal format and will be submitted to The Intemational Joumal of Food Science and Technology. Chapters 1 and 3 are written according to the guidelines outlined in the Publication of the American Psychological Association, 4th edition, 1995. 
Table of Contents

Page

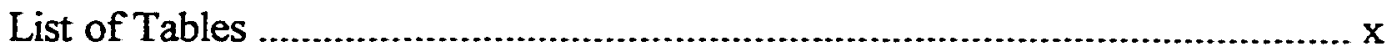

CHAPTER

1 INTRODUCTION AND REVIEW OF THE LITERATURE ............... 1

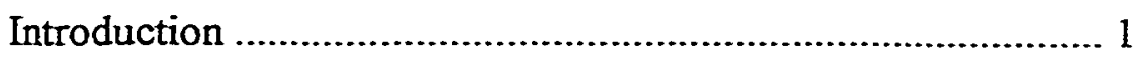

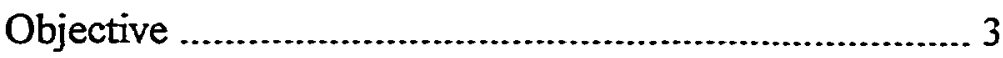

Significance of Study ................................................... 3

Review of the Literature ............................................................. 4

The Banana .................................................................. 4

Spray Drying …............................................................... 8

Factors Affecting Spray Drying .................................... 11

Temperature …................................................. 11

Air Pressure and Flow Rate ............................. 12

Viscosity of Liquid Food ................................... 12

Major Problems in Spray Drying .................... 14

Chemical Composition, Physical Properties, and

Sensory Quality of Spray Dried Powder ..................... 15

Chemical Composition ................................... 16

Proximate Analysis ................................ 16

Potassium Content ................................. 16

Physical Properties ......................................... 18

Bulk Density ........................................ 18

Dispersibility ........................................ 19

Water Activity ..................................... 20 
Page

Browning …..................................................... 20

Sodium Bisulfite .................................... 21

Citric Acid ............................................ 21

Sensory Evaluation ........................................... 22

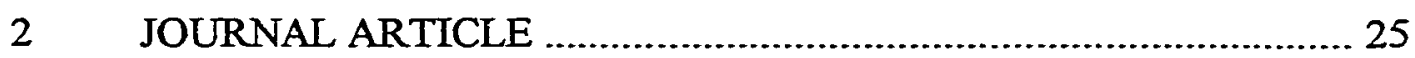

Authors' Title Page ................................................................. 26

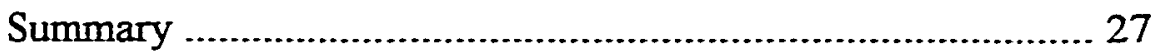

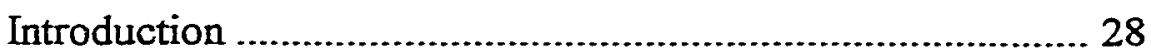

Materials and Methods ........................................................... 30

Sample and Sample Preparation ................................... 30

Proximate Analysis ................................................... 32

Potassium Content ….................................................... 32

Bulk Density and Dispersibility ................................... 33

Water Activity ........................................................... 33

Visual Observations ....................................................... 34

Sensory Evaluation .................................................. 34

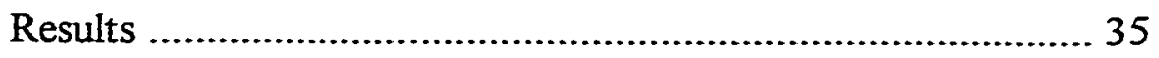

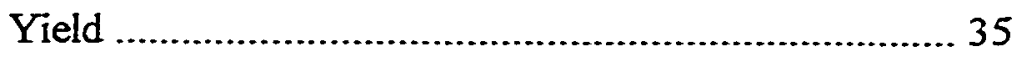

Proximate Composition ................................................. 35

Potassium Content ….................................................. 36

Bulk Density and Dispersibility ................................. 36

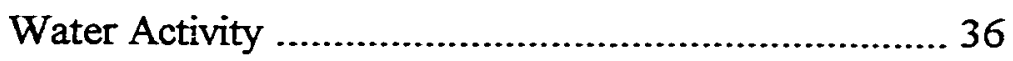

Visual Observations .................................................... 36 


\section{Page}

Sensory Analysis .......................................................... 37

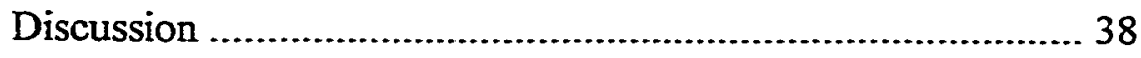

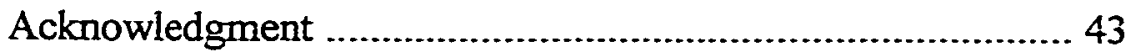

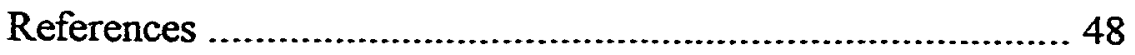

3 SUMMARY AND RECOMMENDATIONS ….............................52

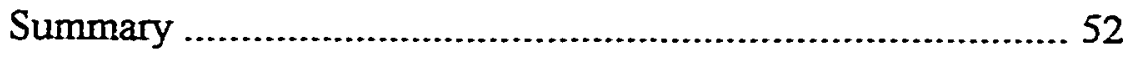

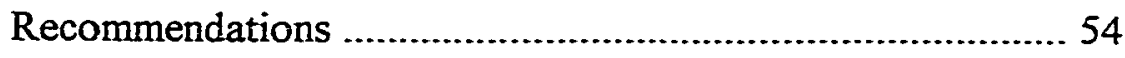

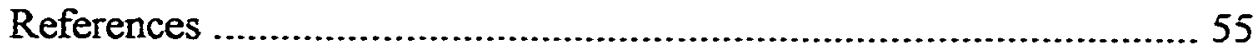




\section{List of Tables}

\section{Page}

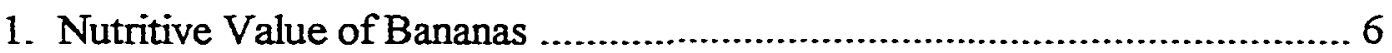

2. Chemical Analysis of Spray Dried Banana and Convection Dried Banana and Tabulated Fresh and Dehydrated Bananas............................ 44

3. Physical Analysis of Spray Dried Banana and Convection Dried

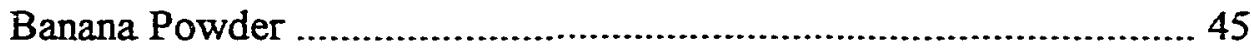

4. Mean Attribute Intensity Ratings for Sensory Scores .......................... 46

5. Analysis of Variance Data for Sensory Analysis Attributes.................... 47 


\section{CHAPTER 1}

\section{INTRODUCTION AND REVIEW OF THE LITERATURE}

Introduction

The banana is one of the most popular fruits in the world. In terms of world trade, the banana production industry was worth $\$ 8$ billion in 1995 (Sexton, 1997). The worldwide production of bananas almost exceeds the production of all citrus fruits combined (Considine \& Considine, 1982). Only grapes exceed bananas with respect to fruit consumption (Forsyth, 1980). World consumption in 1989 was 44 million tons (Daniells, 1993). In most countries average consumption is one to two bananas per person per week (Palmer, 1971).

The banana is a tropical herb of the genus Musa and of the family Musaceae. The common specie of edible banana is the Musa acuminata. The two most common varieties of this edible banana include the Cavendish and the Gros Michel. Other varieties include the Dwarf Cavendish, Lacatan, Poyo, Red Skin, and Silver Skin. It is generally believed that the origin of the genus Musa banana plant is southeastern Asia (Constidine \& Constidine, 1982). Bananas are high in potassium, vitamins $\mathrm{A}_{\text {and }} \mathrm{B}_{6}$, and carbohydrates. They are low in fat, cholesterol, and salt (Forsyth, 1980). Bananas are easily grown year-round in the hot and humid conditions of the tropics. The largest areas of banana production include Brazil, Ecuador, Hawaii, Honduras, Philippines, Puerto Rico, China, and Venezuela. Sixty-two percent of bananas produced world-wide are grown in Latin America (Luh, Kean \& Woodruff, 1986). 
The banana is a climacteric fruit. A climacteric fruit exhibits a rapid rise in respiration which is associated with ripening. There is an inverse relationship between respiration rate and shelf life (Haard, 1984). Due to the climacteric nature of the banana, its shelf life is short, spoilage is almost ensured, and waste is therefore abundant.

Bananas are easily and abundantly produced in tropical areas of the world but only $12 \%$ of all bananas produced are exported (Daniells, 1993). As accumulations exist, bananas spoil, and then, prior to consumption, they are discarded as waste (Fennema, 1975; Forsyth, 1980). Although food waste is caused by a number of factors, such as contamination, damage by pests, inefficient utilization of the nutritious parts of foods, and spoilage, spoilage is considered to be the major cause of waste of the world's fresh food supply (Fennema, 1975). The climacteric nature of the banana fruit, combined with the ease of production and inadequate preservation methods in many developing countries, results in high waste from spoilage (Jayaraman \& Das Gupta, 1992). Spoilage, as well as natural and pest contamination, can be prevented by prompt consumption or more effective preservation techniques (Fennema, 1975).

The high perishability of the banana due to its high moisture content ( $74.3 \%)$, together with its abundant production, over supply, and low cost, has prompted the search for stable food products made from bananas to increase production utilization and take advantage of the nutrients bananas supply (Considine \& Considine, 1982; Fennema, 1975; Valles, 1968). Many preservation methods exist to convert perishable fresh foods into stable products with an extended shelf life. Methods include canning, freezing, and dehydration (Jayaraman \& Das Gupta, 1992). Dehydration, one of the oldest methods of 
food preservation, extends shelf life, reduces weight, preserves the product, and provides convenience with respect to packaging, storage, and transporation (Jayaraman \& Das Gupta, 1992; Mermelstein, 1997). Spray drying has been shown to effectively remove water from many products (Brennan, 1993; Jayaraman \& Das Gupta, 1992; Karel, 1975). Spray drying the ripe banana would change the banana pulp into a fine powder that could be incorporated into other food products, as a food ingredient, thereby enhancing nutritional values of the food products, especially with respect to potassium and vitamins A and $B_{6}$ (Bhandari, Dumoulin, Richard, Noleau \& Lebert, 1992). Examples of food products include baby food, bakery products, candy, and frostings.

\section{Objective}

The objective of this study was to determine the chemical, physical, and sensory characteristics of spray dried banana powder prepared in a laboratory scale co-current flow vertical type of spray dryer. Yield, proximate composition, potassium content, water activity, bulk density, dispersibility, and sensory quality were determined and compared with that of dehydrated banana powder prepared from cabinet convection dried bananas.

\section{Significance of the Study}

Bananas are abundantly and inexpensively produced in hot and humid tropical regions of the world. Due to the fruit's climacteric nature, limited exportation, and nutritive value, methods to preserve this highly perishable fruit have been investigated. Bananas have been dried to form chips and flakes. The key to the preservation of this fruit is the removal of water which can be accomplished through spray drying. Spray 
drying has been effective in removing water from many other food products and may be effective in removing water from, and thereby preserving, ripe bananas. The need for a spray drying process to preserve surplus bananas exists in order to reduce the economical consequences of huge product waste.

\section{Review of the Literature}

\section{The Banana}

The banana, botanically classified as a berry due to its pulpy pericarp and seeds within its flesh, grows on a large tree composed of a pseudostem in tropical regions of the world. The tree grows to a height of 3 to 9 meters ( $\cong 10$ to 30 feet). At a height of about 3 meters $(\cong 10$ feet) the stem, made up of leaves which grow tightly together, begins to open up. The extended leaves can reach out as far as 3 meters ( $\cong 10$ feet). Flower stems with small tubular flowers appear from the center of the pseudostem (Considine \& Considine, 1982; Daniells, 1993). These flowers, once they bave been fertilized, form the fruit. Banana plants are vegetatively parthenocarpic - they do not require pollination in order to develop fruit. Seven to 15 individual fruit (or fingers) form a hand. Groups of hands form bunches. Bunches have anywhere from one to twenty hands. Fingers are usually 15 to 30 centimeters long ( $\cong 6$ to 12 inches) and weigh 50 to 200 grams $\cong 2$ to 7 ounces) and can number up to 300 on a bunch (Daniells, 1993; Simmonds, 1959). There are three stages in the development of the banana fruit: vegetative, floral, and fruit development (Simmonds, 1959). After flowering has occurred it usually takes three to four months until the fruit is harvested (Considine \& Considine, 1982). An acre yields approximately three to seven tons of bananas (Palmer, 1971). 
Bananas are grown in hot and humid tropical countries within $30^{\circ}$ North and $30^{\circ}$ South latitude. Banana plants require continuous moist soil and calm winds. A four inch monthly rainfall and an average monthly temperature of $80^{\circ} \mathrm{F}\left(26.7^{\circ} \mathrm{C}\right)$ is ideal for the growth and yield of this fruit. The banana is a primary food source for people living in most tropical countries (Considine \& Considine, 1982). In parts of East Africa annual consumption can reach 880 pounds ( $400 \mathrm{~kg}$ ) per person (Daniells, 1993). The nutrient values for 100 grams of the edible part of a banana are given in Table 1. Bananas, as part of the fruit and vegetable group, are an important source of nutrients, especially potassium, vitamins $A_{\text {and }} \mathrm{B}_{6}$, and carbohydrates, in the human diet. They also provide color, flavor, and variety, as well as fiber and bulk, to the diet of consumers (Forsyth, 1980; Jayaraman \& Das Gupta, 1992).

Due to their climacteric nature, immature bananas are green and gradually turn to yellow as the fruit matures (Daniells, 1993). Prior to their respiration rise, green bananas are hard, unpalatable, and contain mostly starch. As the fruit ripens this starch is rapidly broken down into sugar, in the form of sucrose (66\%), fructose (14\%), and glucose (20\%). During this ripening stage the fruit becomes soft and sweet, turns from green to yellow due to the reduction of chlorophyll to reveal the carotenoid and xanthophyll pigments, and develops the banana's characteristic aroma. Amylacetate provides the main aroma of a ripe banana. Other aroma substances identified include butyrate, acetaldehyde, ethanol, and methanol. Malic acid is the predominant acid present in the ripe banana. Other acids present include citric, oxalic, and tartaric acids. The $\mathrm{pH}$ drops during ripening from about $5.4 \pm 0.4$ to $4.5 \pm 0.3$. The protein and lipid content remains 
Table 1. Nutritive Value for Bananas*

\begin{tabular}{lc}
\hline Property & Amount \\
\hline Water (\%) & 74.3 \\
Food Energy (kcai) & 92 \\
Protein (g) & 1.0 \\
Fat (g) & 0.5 \\
Ash (g) & 0.8 \\
Carbohydrate (g) & 23.4 \\
Calcium (mg) & 6 \\
Phosphorus (mg) & 20 \\
Iron (mg) & 0.3 \\
Sodium (mg) & 1 \\
Potassium (mg) & 396 \\
Vitamin A value (iu) & 81 \\
Thiamin (mg) & 0.05 \\
Riboflavin (mg) & 0.1 \\
Niacin (mg) & 0.5 \\
Ascorbic Acid (mg) & 9.1 \\
\hline
\end{tabular}

*based on 100 grams, edible portion (cal = calories, $g=$ grams, $\mathrm{mg}=$ milligrams, iu = international units)

Note: From "Composition of Foods" by S. E. Gebhardt, R. Cutrufelli, \& R. H. Matthews (Eds.), 1982, United States Department of Agriculture, Agricultural Handbook No. 8, p. 60, Washington D. C.: United States Government Printing Office. 
relatively unchanged during ripening (Considine \& Considine, 1982; Palmer, 1971; Shewfelt, 1986; Simmonds, 1959). Subsequent ripening results in a watery pulp and brown spots on the peel surface (Simmonds, 1959).

Bananas are picked green to prevent injury or bruising during shipping. They are also picked green in order to control their ripening process during storage. Green bananas are stored at temperatures between $56^{\circ}$ to $58^{\circ} \mathrm{F}\left(13.3^{\circ}\right.$ to $\left.14.4^{\circ} \mathrm{C}\right)$, at a relative humidity of 90 to $95 \%$, and in an atmosphere of high $\mathrm{CO}_{2}$ and low $\mathrm{O}_{2}$ levels. This slows down the ripening process. The bananas are then allowed to ripen as demand for the fruit dictates. Bananas are either allowed to ripen naturally at temperatures from $58^{\circ}$ to $68^{\circ} \mathrm{F}$ $\left(14.4^{\circ}\right.$ to $\left.20^{\circ} \mathrm{C}\right)$ or, more commonly, are commercially subjected to ethylene $\left(\mathrm{C}_{2} \mathrm{H}_{4}\right)$ gas to promote ripening. Ethylene, a hormone produced naturally by climacteric fruits and vegetables, was identified in 1934 as the ingredient that stimulates respiratory activity within the fruit or vegetable which then induces ripening. One cubic foot of ethylene gas is enough to ripen bananas contained in a 1000 cubic foot space (Abeles, 1973; Considine \& Considine, 1982; Eskin, Henderson \& Townsend, 1971). It is commonly believed that ethylene increases cell permeability which leads to enzyme-substrate interactions promoting respiration and ripening (Palmer, 1971). Respiration rate is commonly expressed as the rate of carbon dioxide $\left(\mathrm{CO}_{2}\right)$ produced by a fruit in $\mathrm{mg} / \mathrm{kg} / \mathrm{hr}$ (Hui, 1991). Once ripe, the banana fruit only has a shelf life of two to five days prior to developing dark spots on the surface of the peel. These spots have a damaging effect on the appearance and sensory properties of the bananas and result in consumer reluctance to purchase the product. Such aesthetics contribute to a shorter shelf life and increased 
waste of bananas (Fennema, 1975; Marriott, 1980; McEvily, Iyengar \& Otwell, 1992). This limited shelf life attribute, together with their high moisture content, makes bananas a highly perishable fruit (Jayaraman \& Das Gupta, 1992).

\section{Spray Drying}

Many preservation techniques exist to extend the shelf life of perishable foods. The list includes, but is not limited to, pasteurization, thermal processing, concentration, freezing, dehydration, and drying. Few of these methods have been extended to bananas despite their wide consumption as a fresh fruit (Cano, Marin, \& Fuster, 1990). Four methods of banana preservation have been commercially used: canning, freezing, acid fermentation, and drying (Simmonds, 1959). Drying methods include air, drum, spray, oven, vacuum, and freeze drying. Spray drying involves pumping a concentrated liquid food or puree through a nozzle that forms small droplets that are then sprayed into a chamber with hot air. The interaction of the small liquid droplets with hot air results in rapid heat and mass transfer and produces a fine powdered product. Typical food products that have been produced commercially by spray drying include milk powders, instant coffee and tea drinks, powdered egg products, yeast extracts, and cheese powders (Masters, 1985).

Advantages of spray drying over other methods of dehydration include continuous operation with possibility of automatic control and constant product quality at large throughput rates. A wide range of spray dryer designs are available. In general, there are several specific elements to a spray dryer, including the atomization system, the air- 
handling system, and the device for separating powder from air after drying has been completed (Okos, Narsimhan, Singh, \& Weitnauer, 1992).

The concentrated liquid food is transformed into spherical shaped droplets by an atomizer as the spray nozzle sprays liquid food puree into the drying chamber. The primary purpose of atomization is to increase the surface area of the product. This aids in the rapid evaporation of water at the surfaces. It also determines the size of the droplet particles. The droplets lose water by diffusion but maintain their spherical shape. Morphological changes occur within the droplets as the temperature of these droplets approaches or exceeds $100^{\circ} \mathrm{C}$. Typically, bubbles rise to the surface and burst which results in a collapse of the droplets. The shape of the droplets is set as the final evaporation of water and particle solidification takes place (Boersen, 1990; Karel, 1975; King, 1995; Shahidi \& Han, 1993). Variables that occur within the drying chamber are both difficult to measure and estimate which results in limited documentation as to the actual heat and mass transfer that occurs within the drying chamber (Karel, 1975). Finally, the powder then falls to the bottom of the chamber and is separated from air in the cyclone.

Spray drying is an effective method to dry liquid food products into a powder with an extended shelf life. The shelf life of spray dried food is extended due to the removal of water or moisture. The water in a food product may be free or bound water. Free water is available for chemical and biological reactions; bound water is not available for these reactions. Spray drying removes free but not bound water. However, not all free water is removed. The measurement of free water available for chemical and 
biological reactions in foods is referred to as water activity $\left(a_{w}\right)$. Water activity in foods is measured by the ratio of vapor pressure of the food divided by the vapor pressure of pure water. It is equal to the equilibrium relative humidity (ERH) of a food product divided by 100 . All foods have $a a_{w}$ value less than 1.0. The removal of this free water inhibits the growth of microorganisms and extends the shelf life of the product(s) by decreasing its perishability due to degradative reactions (McWilliams, 1997; Park, 1996; Potter \& Hotchkiss, 1995). Due to the rapid evaporation of water in the dryer the banana product undergoes minimal heat damage because its temperature does not rise significantly (Boersen, 1990; Park, 1996).

A wide variety of products have been successfully spray dried. In a study conducted by Bhandari, Senoussi, Dumoulin \& Lebert (1993) juices of black current, apricot, and raspberry were successfully spray dried at inlet temperatures of 106 to $250^{\circ} \mathrm{C}$. Karel (1975) lists numerous food items that have been successfully spray dried, but identifies milk products (milk, ice cream, cream, and yogurt), coffee, and eggs as among the widely recognized applications of spray drying. Brennan (1993) adds the following dairy products to the list: skim and whole milk, whey, and buttermilk. The author also identifies tea, tomato, and various citrus and other fruits that may be spray dried, but notes that additives, primarily liquid glucose, are needed to facilitate fruit or fruit juice through the spray dryer. Jayaraman \& Das Gupta (1992) have also reported the success of fruit and fruit juice spray drying techniques in their review of recent developments in the dehydration of fruits and vegetables. 


\section{Factors Affecting Spray Drying}

Many factors which affect the spray drying process and the powders formed through this process have been identified. In their study of microencapsulation of citral and linalyl acetate using spray drying, Bhandari et al. (1992) identified viscosity of the liquid food, inlet and outlet temperatures, total solids, proportion of maltodextrin and gum arabic used, and volatile load as important factors. Additional factors such as feed rate, speed of centrifugal atomizer, and the pressure and flow rate of the air were also identified by Bhandari and colleagues (1993). Concentration of solids and maltodextrin may also be of importance (Bhandari et al., 1993).

\section{Temperature}

Inlet and outlet temperatures are important variables in the spray drying of foods (Bhandari et al., 1993). In fact, temperature may be the most important factor of the drying process. The rate of heat transfer increases as the temperature gradient between the food product and the heating medium increases (Park, 1996). The determination of the optimum spray drying temperatures for a particular food to obtain good powder quality is necessary. The inlet temperature needs to be high enough to insure the rapid formation of a dry surface on the droplet. However, the temperature cannot be too high or heat damage to the droplets will occur. Heat damage that is frequently observed is referred to as "ballooning." Ballooning occurs when too high temperatures cause the formation of steam in the interior of the droplet and this steam causes the droplet to puffup which results in a thin-walled hollow droplet. Bhandari et al. (1992) found no ballooning effect until temperatures in excess of $400^{\circ} \mathrm{C}$ were reached. A good mixing of 
the hot air in the drying chamber promotes uniform drying of the droplet particles (King, 1995).

\section{Air Pressure and Flow Rate}

A key element in the spray drying process is the interaction between the atomized feed particles and the hot drying medium (air). Air is taken from the atmosphere, heated, and dispersed into the drying chamber. In a co-current flow spray dryer this occurs near the point of atomization. The flow rate of the hot air is a critical factor in the success of the spray drying operation in terms of achieving quality powder at an optimum production rate (Masters, 1985). When the wet feed particles come in contact with the heated air there is a transfer of heat, mainly by convection, from the air to the solid feed. This heat transfer results in evaporation of water from the feed particles. Another important role of the drying air in the process is that it removes the water vapor from the drying particle surface. This allows for further evaporation of water from the feed particles (Brennan, 1993). Air pressure and flow rates can be predicted or experimentally determined. They are dependent on the type of atomizer, air dispersion system, design of the dryer, and nature of the feed. Preliminary testing can determine the optimum air pressure and flow rate for a particular drier and feed product (Masters, 1985).

\section{Viscosity of Liquid Food}

Ripe raw banana has approximately 26 percent soluble solids. Maltodextrin can be used to increase the viscosity of the banana puree without adding sweetness (Ockerman, 1991). Bhandari et al.(1993) reported an increase in powder yield when total dry matter in the juice feed was increased by the addition of maltodexrin. 
Maltodextrins $\left[\left(\mathrm{C}_{6} \mathrm{H}_{12} \mathrm{O}_{5}\right)_{\mathrm{n}} \mathrm{H}_{2} \mathrm{O}\right]$ are obtained from the partial or enzymatic hydrolysis of starch. They are composed of approximately $65-80 \%$ high saccharides, 4 $9 \%$ pentasaccharides, $4-7 \%$ tetrasaccharides, and $5-9 \%$ trisaccharides. They also contain trace amounts of mono- and disaccharides (Ockerman, 1991). Maltodextrins are defined by the FDA as nonsweet, nutritive polysaccharides consisting primarily of alpha-1-4-Dglucose with a dextrose equivalent (DE) less than 20. At a higher DE the product is called corn syrup solids (Shahidi \& Han, 1993). Dextrose equivalent is the measure of the amount of free dextrose (glucose); pure glucose equals $100 \mathrm{DE}$ (McWilliams, 1997). Maltodextrins are used as a bodying and bulking agent, tenderizer, carrier, and crystallization inhibitor. They also increase viscosity (Igoe \& Hui, 1996; Kenyon \& Anderson, 1988; Shahidi \& Han, 1993). Maltodextrins are usually found in the form of a white powder (Lopez, 1987).

Maltodextrins possess two qualities which make them desirable to the food processing industry. First, they have a selectively high molecular weight which results in their high viscosity and minimal sweetness. However, as the DE of the maltodextrin increases, the molecular weight decreases (Desobry, Netto \& Labuza, 1997). Second, they have a low reducing power and, as a result, participate very little in browning reactions (Lopez, 1987). Maltodextrins do not add sweetness to foods and are generally recognized as safe (GRAS) as a food ingredient (Kenyon \& Anderson, 1988; Ockerman, 1991). Only good manufacturing practices, as stated in 21 CFR 185.1444 (c), limit the use of maltodextrins in food products (Food and Drug Administration, 1998). 
Bananas, as well as other fruits such as apples, pears, strawberries, peaches, and apricots, require fillers such as maltodextrin in order to pass through the spray dryer. Without maltodextrin the fruit feed is sticky and the product will tend to cake (Brennan, 1993). In their examination of black current, apricot, and raspberry juices, Bhandari et al. (1993) used maltodextrins of different $\mathrm{DE}$ values $(6,12$, and 19) to determine under which conditions did maltodextrin optimally carry concentrated fruit juices through a spray drier. The ability to promote the efficiency of this process varied by type of juice and the DE of the maltodextrin. The authors found that maltodextrin with a DE of 6 produced the best result and that the ratio of fruit juice to maltodextrin amount varied between the juices. The ratios that produced the best spray dried powder were 65:35 for black current, 60:40 for apricot, and 55:45 for raspberry juices. Maltodextrin with a DE of 17 was used with gum arabic, in different proportions, by Bhandari and colleagues (1992) in their use of spray drying to achieve flavor encapsulation of citral and linalyl acetate.

Shew \& Rosenberg (1995) used spray drying to microencapsulate whey protein isolate with the aid of maltodextrins and low dextrose-equivalence corn syrup. Other carriers used in spray drying food products include gelatin, modified starch, nongelling protein, and vegetable gums (Shahidi \& Han, 1993).

\section{Major Problems in Spray Drying}

Problems associated with spray drying fruit products include stickiness and adhesion to the drying chamber walls, stickiness between particles resulting in agglomeration, and collection and handling difficulties. These problems occur because 
fruits are high in sugar and if they touch a dry chamber wall before they are dry they will stick to it and, as other particles touch them and stick, buildup and heat damage will occur (Bhandari et al., 1993; Jayaraman \& Das Gupta, 1992; Papadakis \& Bahu, 1992; Potter \& Hotchkiss, 1995). Agglomeration inhibits the drying of the particles inside the drying chamber. Particle adhesion to the chamber walls results in a decreased yield of product, additional cleaning requirements, and powder collection and handling difficulties (Papadakis \& Bahu, 1992). Karel (1975) and Bhandari et al. (1993) note that cooling the drying chamber walls decreases the amount of powder that sticks. Other approaches to decrease sticking tendencies include adding maltodextrin as a drying agent, in concentrations of at least $15 \%$ dry basis, and the design and development of special spray dryer chambers for feeds which tend to stick (Papadakis \& Bahu, 1992).

\section{Chemical Composition, Physical Properties and}

\section{Sensory Quality of Spray Dried Powder}

Quality measurements that were used to identify the quality characteristics of spray dried bananas include proximate analysis, potassium content, bulk density, dispersibility, and water activity. A consumer sensory evaluation examining color, odor, taste, texture, and overall acceptability was also deemed desirable to establish the quality of spray dried banana powder.

In their study of fruit juice spray drying, Bhandari et al. (1993) analyzed their powdered fruit juices using water content, bulk and pack density, sticky point temperature, and particle size as measurements of powder quality. In addition to bulk density and moisture content, Onwulata, Smith, Craig \& Holsinger (1994) also used 
powder flow as a quality measurement. Other measurements may include color, flavor intensity, and dispersibility (Jayaraman \& Das Gupta, 1992; Mizrati, Berk \& Cogan, 1967).

\section{Chemical Composition}

Proximate Analysis. Proximate analysis includes moisture, crude fat, crude protein, ash, and total carbohydrate content. This analysis was determined by standard procedures used by the Association of Official Analytical Chemists $(1990,1995)$. The moisture content of a food product affects its quality and stability during processing (Park, 1996). Due to the fact that moisture greatly affects the quality and stability of foods, it is an important and a frequently used analytical measurement in food processing and product testing (Joslyn, 1970a; Park, 1996). The moisture content of spray dried food powders typically ranges from one to four percent (Onwulata et al., 1994). Fat and oil in food products have three common characteristics: they are insoluble in water, slightly soluble in alcohol, and are readily dissolved in solutions of ethyl ether, petroleum spirit, carbon disulfide, and carbon tetrachloride (Joslyn, 1970b). The fat content of fruit is less than $0.5 \%$ (except for olives and avacados). The fat content of fresh bananas is $0.48 \%$ (USDA, 1982). The total carbohydrate content of the banana powder is assumed to be $100 \%$ minus the combination of the $\%$ moisture, $\%$ crude fat, $\%$ crude protein, and $\%$ crude ash. This is considered the classical method of carbohydrate determination (Peris-Tortajada, 1996).

Potassium Content. Retention of the nutritive values of the banana during spray drying is critical if the powder is to be used as a food ingredient. Bananas are high in 
potassium and vitamins $B_{6}$ and $A$. These nutrients need to survive the spray drying process if researchers expect acceptance of spray dried banana powder as a food ingredient by food processors. Established methods exist to determine the potassium, vitamin $\mathrm{B}_{6}$, and vitamin $\mathrm{A}$ contents of the banana powder.

Potassium $(\mathrm{K})$, together with sodium $(\mathrm{Na})$ and chloride $(\mathrm{Cl})$, is an electrolyte. Potassium functions with $\mathrm{Na}$ and $\mathrm{Cl}$ in maintaining fluid balance and volume (Leveille, Zabik, \& Morgan, 1983). Sodium and $\mathrm{Cl}$ are the principle electrolytes for extracellular fluid while $\mathrm{K}$ is the principle electrolyte for intercellular fluid (Holiday, 1988). Potassium is also involved in carbohydrate metabolism, protein synthesis, muscular contractions, and nerve impulse conduction. Potassium is found in fruits, vegetables, grains, and most meat and dairy products (Leveille et al., 1983).

One hundred grams of fresh raw banana contains approximately $396 \mathrm{mg}$ of potassium (USDA, 1982). Processing decreases the amount of potassium in a food product (Leveille et al., 1983). The atomic absorption spectrophotometric method (AOAC $977.29,1990$ ) was used to determine the $\mathrm{K}$ content of the spray dried banana powder.

Elements of the periodic table have a specific number of electrons which orbit the nucleus in a normal or "ground" state. When light energy is applied, some of these electrons move to a less stable configuration ("excited" state). As an atom moves from a ground to excited state it absorbs energy (Perkin-Elmer Corporation, 1982). The amount of energy absorbed is proportional to the number of free atoms that can absorb the energy. Atomic absorption spectroscopy reliably and accurately measures the amount of 
radiant energy absorbed by the free atoms (Robinson, 1975). Specific quantitative determination of elements can be accomplished through this analytical method. Atomic absorption spectroscopy is a relative method of analysis (Welz, 1985). Determinations of element concentration can be made only if there is some way to compare the results with reference solutions. Reference solutions are used to establish calibration curves (Robinson, 1975). The absorption of solutions of known concentration are measured and a curve is then plotted with absorption on the $y$-axis and concentration on the $\mathrm{x}$-axis. Then the absorbance of a solution of unknown concentration can be measured and plotted. The unknown concentration can then be determined from the calibration curve. Physical Properties

Bulk Density. Bulk density is an estimate of the volume a powdered food occupies when it is packaged and stored or when it is used in food preparation (Svarovsky, 1987). The bulk density of a food powder is dependent upon three factors: 1) particle size, 2) interparticle attractive forces, and 3) the physical contact points between particles. Any one of these parameters can change the magnitude of the bulk density of the powder (Peleg, 1983).

The tapping method, as opposed to the poured or aerated methods, was used to determine bulk density which is expressed in grams per cubic centimeter $\left(\mathrm{g} / \mathrm{cm}^{3}\right)$. Twenty grams of banana powder was put into a $100 \mathrm{ml}$ graduated cylinder, compacted by tapping onto a flat surface 10 times from a height of 15 millimeters $(\mathrm{mm})$, and the final volume recorded. Bulk density is defined as the ratio of sample weight ( $\mathrm{g}$ ) divided by the sample volume $\left(\mathrm{cm}^{3}\right)$. Most food powders have a bulk density between 0.3 and $0.8 \mathrm{~g} / \mathrm{cm}^{3}$ 
(Bhandari et al., 1993; Chang, Scire, \& Jacobs, 1988; Onwulata et al., 1994; Peleg, 1983; and Svarovsky, 1987).

Dispersibility. The capability of a food powder to be distributed throughout water, instead of clumping together, is a measure of dispersibility (Masters, 1985). A powder must have certain characteristics in order to rapidly and completely disperse in water. These characteristics include having a large surface area, the ability to sink instead of float on the surface, solubility, and a resistance to sedimentation (Karel, 1975). No scientific method for dispersibility of powder exists so a method had to be developed to measure this variable. A modification of three previously reported designs was developed. The primary method followed was one proposed by Arbuckle (1973) for analysis of dry milk powder. However, agitation and temperature of $20^{\circ} \mathrm{C}$ were also used in the design. Agitation was used by Al-Kahtani \& Hassan (1990) to disperse spray dried Roselle extract into water. Bhandari et al. (1993) used a water temperature of $20^{\circ} \mathrm{C}$ to disperse $12 \mathrm{~g}$ of their spray dried fruit juices Dispersibility was determined by gently pouring $10 \mathrm{~g}$ of banana powder onto a water surface ( $100 \mathrm{ml} \mathrm{H}_{2} \mathrm{O}$ in a $250 \mathrm{ml}$ beaker) with a temperature of $20^{\circ} \mathrm{C}$ and then measuring the time it takes for the powder to be well dispersed in the water. This procedure was also repeated with boiling water for comparison purposes. Visual observations were also made. Well dispersed is defined as having no particles settling on the bottom and no particles floating on the surface. Dispersibility involves three activities: the wetting of the surface of the powder particles, which usually results in some clumping, the break up of the wetted clumps, and the maintenance of particle separation (Nelson, 1988). 
Water Activity. There is a relationship between water activity $\left(a_{w}\right)$ and microbial growth and most biological, chemical, and enzymatic reactions (the primary exception being lipid oxidation). Flavor, texture, color, and stability of nutrients are also affected by $a_{w}$ (McWilliams, 1997; Potter \& Hotchkiss, 1995). It is often useful to measure $a_{w}$ due to its relationship with perishability and microbial growth.

Browning

While most of the pigments in a banana are located in the peel, the pulp contains three major pigments, in very low concentrations, which contribute to its color. These include lutein, alpha-carotene, and beta-carotene (Shewfelt, 1986). Although bananas and banana products are affected by both enzymatic and nonenzymatic browning reactions, they are very susceptible to rapid discoloration once they are peeled due to enzymatic browning which involves the oxidation of these pigments by the enzyme polyphenol oxidase, also known as phenol oxidase, tyrosenase, monophenol oxidase, or cresolase (McEvily et al., 1992; Shewfelt, 1986; Weaver \& Charley, 1974). This browning causes problems in the food industry because it not only changes the appearance of fruits and vegetables but also changes the sensory properties and nutritional quality of the fruit and/or vegetables as well (Molnar-Perl \& Friedman, 1990). Enzymatic browning affects the quality and appearance of foods. It is therefore necessary to prevent such browning to ensure consumer acceptance of the fruit. Heat, as well as certain chemical additives, inhibit enzymatic browning (Considine \& Considine, 1982). 
Sodium Bisulfite. Sodium bisulfite $\left(\mathrm{Na}_{2}\left(\mathrm{SO}_{4}\right)_{2}\right)$ is a common chemical additive used to prevent enzymatic browning (Masters, 1985). Sodium bisulfite inhibits the enzymes that cause browning and is commonly used in the food and beverage industries to control such browning (McEvily at al., 1992). The use of $\mathrm{Na}_{2}\left(\mathrm{SO}_{4}\right)_{2}$ is only limited by good manufacturing practices, according to 21 CFR 182.3739(c). However, it cannot be used in meats, foods that are a source of vitamin $B_{1}$, on fruits and vegetables that will be consumed raw, or on foods that will be offered as fresh (FDA, 1998).

Sodium bisulfite has been reported to be a food irritant known to be the cause of some health problems because some of the populace are severely allergic to it resulting in many illnesses, some serious (especially among steroid-dependart asthmatics). Indeed, sulfite additives have been linked to 13 deaths. The negative implications associated with the use of sulfite additives has led to the search for alternatives to prevent enzymatic browning in foods (Langdon, 1987; McEvily et al., 1992; Potter \& Hotchkiss, 1995).

Citric Acid. Citric Acid $\left(\mathrm{C}_{6} \mathrm{H}_{8} \mathrm{O}_{7}\right)$ is an alternative chemical additive that can be added to prevent enzymatic browning (Considine \& Considine, 1982). Citric acid is an organic acid that is produced by mold fermentation of sugar solutions. It is also an antioxidant (Igoe \& Hui, 1996). Citric acid is the most commonly used acid to prevent browning and may be an alternative to $\mathrm{Na}_{2}\left(\mathrm{SO}_{4}\right)_{2}$ to prevent browning of the banana pulp during spray drying. Treatment of 0.5 to $2.0 \%$ weight/volume is used in the food industry to control enzymatic browning. This acidulant inhibits polyphenol oxidase in two ways. First, it lowers the $\mathrm{pH}$ to a level not optimal for activity of this enzyme; and second, it acts as a chelating agent. As a chelating agent, citric acid can form a complex 
with the copper found at the enzyme-active site of polyphenol oxidase. Copper is then not able to be released, in ion form, to participate in reactions that lead to, among other things, discoloration in foods (Fennema, 1996; McEvily et al., 1992).

Although citric acid is the most widely used acid in the food industry, there are other organic and inorganic alternatives such as malic, tartaric, and malonic (organic) acids, and phosphoric and hydrochloric (inorganic) acids (McEvily et al., 1992).

\section{Sensory Evaluation}

Sensory evaluations are used frequently when examining new food products or food products that have been processed using an alternative method, such as spray drying, with the goal of predicting potential consumer acceptance of the product(s). When Malundo, Resurreccion, \& Koehler (1992) examined spray drying peanut extracts to produce a coffee whitener, they used consumer panels, consisting of 24 untrained judges, to evaluate solubility, whitening power, appearance, acceptability, and flavor. A nine-point scaling method with descriptors at both ends and in the center were used. The authors' objective was to see if they might acceptably use peanut extract instead of sodium caseinate when producing a spray dried coffee whitener.

Aguilar, Hollender, \& Ziegler (1994) also used sensory evaluation to determine whether spray-dried, high-lactose whole-milk powders could be substituted for sucrose in milk chocolate. The authors wanted to examine the use of lactose in milk chocolate to see how it related to flavor, texture, sweetness, and processing. A six member, trained sensory panel evaluated seven flavor and four texture attributes. Analysis of variance 
(ANOVA) was used in both studies to detect significant differences between the different methods of preparation. In both cases some significant differences were found.

Color. Appearance characteristics or attributes include size and shape, surface texture, clarity, carbonation, and color (Meilgarrd, Civille, \& Carr, 1991). According to R. W. Rothery, Ph.D. (personal correspondence, January 31, 1999), color is the result of light being retransmitted from, rather than fully absorbed within, an object. It is typically described in terms of hue, saturation, and brightness (Stein, 1975). The color of a food product, or ingredient, shapes the human perception of the appearance of the food. How people see, and expect to see, a food item is related to their expectation, preference, and acceptance of that item although color does not necessarily reflect a guarantee of flavor, nutrients, and functional attributes (Francis, 1983). Color can be measured by instrumentation and sensory measurements. Intensity and wavelength are the measurable variables used when describing the color, a characteristic of light, in foods (Pomeranz \& Meloan, 1978). Human panelists can also be used to assess perceived color qualities in foods.

Odor. The odor of a food product is referred to as aroma. Aroma is perceived by humans when volatiles from a food in or near the mouth enters the nasal cavity and are sensed by the olfactory mucosa located in the roof, septum, and superior turbinates of the nasal cavity (Maruniak \& Mackay-Sim, 1984; Meilgarrd et al., 1991). Odors can reach the olfactory mucosa in two different ways. First, they can be inhaled through the nostrils. Second, during chewing or swallowing they can travel from the mouth to the nasal cavity (Menella, 1998). 
Taste. Humans perceive taste when food, dissolved in oil, water, or saliva, flows into their taste buds located on the surface of their tongue, in the mucosa of their palate, and in some areas of their throat. Taste is affected by concentration of the food being sampled, temperature and viscosity of the sample, rate and duration of exposure, area of application of the food in the mouth, the chemical state of a person's saliva, and the presence of other samples being tested in the saliva (Meilgarrd et al., 1991).

Texture. Texture is less studied than taste, odor, and appearance and is a complex and important sensory attribute because it is often cited as the reason for disliking rather than liking a food item (Cardello, 1994). It has been defined as "the sensory and functional manifestation of the structural and mechanical properties of foods, detected through the sense of vision, hearing, touch, and kinesthetics" (Sczczesniak, 1998, p. 55). Meilgarrd et al. (1991) list these components of texture: mechanical properties include hardness, cohesiveness, adhesiveness, denseness, and springiness; geometrical properties include smoothness, gritty, grainy, chalky/powdery, fibrous, and lumpy/bumpy; and moisture properties include moistness, moisture release, oily, and greasy. In addition, Sczczesniak adds viscosity to mechanical properties and particle size to geometrical properties. 


\section{CHAPTER 2}

JOURNAL ARTICLE 
Authors' Title Page

\section{CHEMICAL, PHYSICAL, AND SENSORY CHARACTERISTICS OF SPRAY DRIED BANANA POWDER}

Laura A. Hawkins, Panfilo S. Belo , Miriam Saltmarch, and Lucy McProud Department of Nutrition and Food Science

San Jose State University

1 Washington Square

San Jose, CA 95192-0058

U.S.A.

\footnotetext{
* Address questions and comments to: Dr. Panfilo S. Belo, Department of Nutrition and Food Science, San Jose State University, 1 Washington Square, San Jose, CA 95192-0058, U.S.A., 408-924-3108.
} 


\section{Summary}

The objective of this study was to determine the chemical, physical, and sensory characteristics of spray dried banana powder produced under laboratory scale conditions. Banana puree containing $8.9 \%$ maltodextrin was spray dried in a co-current flow vertical type of spray dryer. Yield, proximate composition, potassium content, water activity, bulk density, dispersibility, and sensory quality of the resulting powder were determined and compared with that of dehydrated banana powder prepared from cabinet convection dried bananas.

Spray dried banana powder has a moderate potassium content, is low in fat and protein, and high in carbohydrates. The spray dried powder has a bulk density similar to other food powders $\left(0.3\right.$ to $\left.0.8 \mathrm{~g} \mathrm{~cm}^{-3}\right)$. A sensory evaluation revealed that the taste of spray dried banana most closely matched the fresh banana while its odor and texture did not. Overall acceptability was influenced most by odor and texture, rather than color and taste.

Keywords: spray drying, banana powder 


\section{Introduction}

The banana is a tropical herb of the genus Musa and of the family Musaceae. It is easily and abundantly grown in hot and humid tropical countries within $30^{\circ}$ North and $30^{\circ}$ South latitude (Constidine \& Constidine, 1982). Bananas are high in potassium, vitamines $A$ and $B_{6}$, and carbohydrates. They are low in fat, cholesterol, and salt. Bananas also provide color, flavor, and variety, as well as fiber and bulk, to one's diet (Forsyth, 1980; Jayaraman \& Das Gupta, 1992). Bananas are a climacteric fruit and, as such, experience a rise in respiration associated with ripening. Many changes occur to the fruit during ripening: starch is broken down into sugar, the hard and unpalatable fruit becomes soft, the color of the fruit peel turns from green to yellow due to the reduction of chlorophyll to reveal the carotenoid and xanthophyll pigments, the characteristic "banana" aroma develops, and the fruit becomes more acidic as the $\mathrm{pH}$ drops from about $5.4 \pm 0.4$ to $4.5 \pm 0.3$ (Constidine \& Constidine, 1982; Palmer, 1971; Shewfelt, 1986; Simmonds, 1959).

Once ripe, a banana only has a shelf life of about two to five days prior to developing dark spots on the surface of the peel. These spots have a damaging effect on the appearance and sensory properties of the banana and result in an increase in consumer reluctance to purchase the product. This contributes to a shorter effective shelf life and increased waste of bananas (Fennema, 1975; Marriott, 1980; McEvily et al., 1992). The banana also has a high moisture content (74.3\%) which makes it a highly perishable fruit. These factors, combined with the abundant production, over supply, and low cost of the fruit, has prompted the search for new uses of stable food products made from bananas to 
reduce produce waste and take advantage of the nutrients bananas supply (Constidine \& Constidine, 1982; Fennema, 1975; Valles, 1968).

Many preservation methods exist but few have been extended to bananas despite their wide consumption as a fresh fruit (Cano et al., 1990). One of the oldest methods of preservation is dehydration. The removal of water not only extends the shelf life of the product but also reduces product weight, preserves the product, and provides convenience with respect to packaging, storage, and transportation (Jayaraman \& Das Gupta, 1992; Karel, 1975). One of the most economical methods of water removal is spray drying (Bhandari et al., 1992).

Spray drying is an effective and common method to dry liquid food products into a powder with an extended shelf life (Brennan, 1993; Park, 1996). A wide variety of products have been successfully spray dried. Bhandari et al. (1993) successfully spray dried the juices of black current, apricot, and raspberry. Other food items that have been successfully spray dried include milk products, coffee, eggs, tea, tomatoes, and various citrus fruits (Brennan, 1993; Karel, 1975). The use of maltodextrin has been shown to facilitate the spray drying process of many fruit products such as apples, pears, strawberries, peaches, and apricots (Brennan, 1993). However, maitodexrin has not been used to facilitate the spray drying of bananas. Maltodextrins, obtained from the partial or enzymatic hydrolysis of starch, are used as a bodying and bulking agent, tenderizer, carrier, and crystallization inhibitor (Igoe \& Hui, 1996). They do not add sweetness to foods. Maltodextrin additives help facilitate the banana puree through the spray dryer. Bhandari et al. (1993) used maltodextrins of different dextrose equivalents (DE) to 
determine the conditions under which maltodextrin optimally carried concentrated fruit juice through the spray dryer.

The objective of this study was to determine the chemical, physical, and sensory characteristics of spray dried banana powder produced under laboratory scale conditions. The spray drying of banana puree into a dry powder material may provide a finished powdered product that not only has an extended shelf life, but produces a stable product that can be incorporated into processed food products as a nutritious food ingredient. Examples of such food products include baby food, bakery items, candy, and frostings. Proximate composition, potassium content, bulk density, dispersibility, water activity and sensory comparisons were made between spray dried banana (SDB) and convection dried banana $(\mathrm{CDB})$ powders.

\section{Materials and Methods}

Sample and sample preparation

Bananas were purchased at a local supermarket. The bananas were allowed to ripen, at room temperature, to the point that the development of brown spots on the peel would deem them overripe and unacceptable to consumers. Maltodextrin was obtained from Cerestar USA, Inc. (Hammond, IN, USA). Maltodextrin additives were utilized in this study as a carrier to help facilitate the banana puree through the spray drier. Bananas from the same hands (consisting of 7 to 15 individual fruit) were used to prepare both SDB powder and CDB powder. The bananas were peeled, cored, and sliced. The slices were homogenized, using a common kitchen blender, with water and maltodextrin (DE = 5) for $60 \mathrm{~s}$. Each batch for spray drying consisted of $80 \mathrm{~g}$ banana, $125 \mathrm{ml}$ water, and $20 \mathrm{~g}$ 
maltodextrin. Total solids and moisture content for each batch were $40.6 \mathrm{~g}$ and $184.4 \mathrm{~g}$, respectively. This proportion of solids to water yielded the most powder, as was determined by trial runs conducted over a three week period prior to this study. The banana samples to be convection dried were also manually peeled, cored, sliced, and placed (single layer) on a screen in a Harvest Maid ${ }^{T M}$ convection food dehydrator $\left(63^{\circ} \mathrm{C}\right)$ overnight $(\cong 20 \mathrm{~h})$. The dried banana slices were then ground, using a coffee bean grinder, into a powder. CDB powder was generated on six occasions over a five week period. The total amount produced was $280.7 \mathrm{~g}$. Percent yield was $25.3 \%$.

A series of preliminary experiments were conducted to attain optimum operating conditions of the laboratory spray dryer. Several tests were carried out to establish the optimum concentration of maltodextrin that would facilitate the spray drying process. Optimum inlet and outlet temperatures, feed rate, and air pressure and flow rate were also established on the basis of efficiency to produce quality powder in sufficient quantity for analysis. Manufacturer recommendations and literature values were also taken into consideration in arriving at optimum operating conditions.

The banana puree was spray dried using a Yamato ${ }_{\circledast}$ Pulvis Mini-spray co-current flow vertical spray dryer (Yamato USA, Inc., Northbrook, II, USA). The spray dryer was operated at an inlet temperature of $190^{\circ} \mathrm{C}$ and an outlet temperature of $105 \pm 6^{\circ} \mathrm{C}$. Other parameters included: pressure at $0.5 \mathrm{kgf} \mathrm{cm}^{-2}$, air speed of $0.4 \mathrm{~m}^{3} \mathrm{~min}^{-1}$, and pump speed of 2 . These parameters were based on a literature review and the preliminary trial tests. SDB powder was generated on 20 occasions over a six week period. The total amount produced was $197.2 \mathrm{~g}$. Percent yield was $12.6 \%$. To avoid possible degradation 
due to light, air, and/or heat, all banana powder samples were stored in tightly sealed jelly jars in the refrigerator until analyses were made.

Proximate analysis

Moisture, crude fat, crude protein, and ash content of the two powder samples were determined by standard procedures used by the Association of Official Analytical Chemists $(1990,1995)$. The total carbohydrate content of the banana powders was determined by difference, subtracting the percentage of moisture, crude fat, crude protein, and ash from $100 \%$. Moisture and ash measurements were done in duplicate. The measurement of crude fat and crude protein was done in triplicate.

\section{Potassium content}

The potassium content was determined using the ash samples obtained in the proximate determination of ash content. The atomic absorption spectrophotometric method (AOAC, 1990) was used. Standard atomic absorption parameters for K are: wavelength, $766.5 \mathrm{~nm}$ and slit, $1.4 \mathrm{~nm}$, as specified by the manufacturer's guide (PerkinElmer Corporation, 1982).

Calibration was done using standard solutions (1.2, 3.0, 9.0, 10.0, and $19.0 \mathrm{ppm})$ prior to sample evaluation and a calibration graph was prepared. The ash samples were dissolved in $\mathrm{HCl}$ and diluted using deionized water. Sample concentrations were 0.2 and $0.3 \mathrm{ppm}$ for the CDB and SDB powder, respectively. Absorbency values were observed and recorded. Potassium was read from the calibration curve. Evaluation of the potassium content of the two powder samples was done in duplicate. 


\section{Bulk density and dispersibility}

The tapping method used by Bhandari et al. (1993) to determine the bulk densities of fruit juice powders was followed to determine bulk density $\left(\mathrm{g} \mathrm{cm}^{-3}\right)$ of the banana powders. Approximately twenty grams of powder was transferred to a $100 \mathrm{ml}$ graduated cylinder, compacted by tapping onto a flat surface 10 times from a height of $15 \mathrm{~cm}$, and the final volume recorded. Grams of powder divided by volume equals bulk density. This measurement was done in triplicate for each sample and the results averaged.

Due to the lack of a standard method to determine the dispersibility of a food powder, a method of analysis was developed following modification of three previously reported designs (Arbuckle, 1973; Al-Kahtani \& Hassan, 1990; and Bhandari et al., 1993). Dispersibility of the powders was determined by pouring $100 \mathrm{ml}$ of distilled $20^{\circ} \mathrm{C}$ water into a $250 \mathrm{ml}$ beaker. Agitation of the water was accomplished by the use of a magnetic stirrer (setting 5). Then $10 \mathrm{~g}$ of powder was gently poured on to the surface of the water and the time (m) for the powder to be well dispersed was recorded. "Well dispersed" was defined as having no particles settling on the bottom and no particles floating on the surface. Measurements were made in duplicate and visual observations recorded and reported.

Water activity

A Rotronic Hygroskop DT (Rotronic Instrument Corporation, Huntington, NY, USA) was used to measure the water activity $\left(a_{w}\right)$ of the two banana powders. The instrument was first calibrated using ammonium sulfate $\left(\left(\mathrm{NH}_{2}\right)_{4} \mathrm{SO}_{4} ; 81 \% \mathrm{RH}\right.$ at $\left.20^{\circ} \mathrm{C}\right)$. 
Triplicate measurements were conducted for both powder samples and the results averaged.

Visual observations

The SDB powder was very light yellow in color. Visual observations of browning were made when the powders $(2 \mathrm{~g})$ were placed into room temperature and into boiling water $(6 \mathrm{ml})$ and mixed.

Sensory evaluation

To determine the overall consumer preferences of the dried banana samples, spray dried, convection dried, and fresh banana samples were prepared for a sensory evaluation. Fresh banana (FB) samples (moisture content $74.3 \%$ ) were blended using a common kitchen blender. The dried banana samples were blended with water to achieve the same moisture content as the $\mathrm{FB}\left(\mathrm{CDB}=131.25 \mathrm{mg} \mathrm{H} \mathrm{H}_{2} \mathrm{O}+48.24 \mathrm{~g}\right.$ powder; $\mathrm{SDB}=$ $131.25 \mathrm{ml} \mathrm{H}_{2} \mathrm{O}+45.38 \mathrm{~g}$ powder). No other ingredients were added. The samples (7.5 $\mathrm{ml}$, room temperature) were presented in $11 \mathrm{ml}$ disposable paper cups coded with threedigit random numbers picked from a table of random numbers. Order of presentation was randomized. Samples were expectorated after evaluation. Room temperature deionized water was provided for rinsing between samples.

An 18 member panel, mainly students, was used to evaluate the banana purees. The panel, consisting of 15 women and 3 men, evaluated the yellow color, odor pleasantness, likeness of taste, smoothness of texture, and overall acceptability of the samples using a $5 \mathrm{~cm}$ unstructured line scale with anchored terms at each end. Scores ranged from 0 to 5 for each attribute. The anchors were: light yellow (5) and dark 
yellow (0) for color; pleasant (5) and unpleasant (0) for odor; extreme like (5) and extreme dislike (0) for taste; smooth (5) and watery (0) for texture; and excellent (5) and poor (0) for overall acceptability. The panelists were familiar with attribute scaling tasks prior to data collection as they had participated in other evaluations (not reported here), but were not trained for this particular study. Each treatment was evaluated only once by each panelist. Analysis of variance (ANOVA) and Least Significant Difference (LSD) were used to test significant differences between the different methods of preparation at $p$ $<0.05$.

Results

Yield

The percent yield was $12.6 \%$ for the spray dried banana samples and $25.3 \%$ for the convection dried banana samples.

Proximate composition

Proximate composition varied between the two samples of dried banana. A comparison between the $\mathrm{CDB}$ and SDB samples shows significant differences between the two samples with respect to moisture and protein while the fat, ash, and carbohydrate differences varied less. A complete summary of the proximate analysis means for the two powders, as well as fresh and dehydrated banana (USDA, 1982), is presented in Table 2. When compared to dehydrated (DHYB) banana values from a food composition table (USDA, 1982), the SDB powder had a similar moisture content but percent protein, fat, and ash were much less. 


\section{Potassium content}

The mean values of potassium in spray dried, convection dried, fresh, and dehydrated banana are found in Table 2 . While the CDB powder exceeded the DHYB banana with respect to potassium (measured in $\mathrm{mg} \mathrm{K}^{-1}$ banana) content, the SDB powder potassium content was relatively low.

Bulk density and dispersibility

The bulk density of the SDB powder was $0.43 \mathrm{~g} \mathrm{~cm}^{-3}$. The bulk density of the CDB powder was $0.84 \mathrm{~g} \mathrm{~cm}^{-3}$ (Table 3). Neither SDB nor CDB dispersed well in room temperature water (Table 3). Both samples floated on the surface before forming a big clump that eventually disappeared from the surface. The clumps did break up with continued agitation. Disappearance from the surface and clump breakup was faster for the CDB samples than the SDB samples. Increased water temperature facilitated the dispersions of both powders.

Water activity

The mean $a_{w}$ values for the two powder samples are found in Table 3. Both powder samples have low $\mathrm{a}_{\mathrm{w}}$.

\section{Vistual observations}

The light yellow SDB powder, upon being mixed with both room temperature and boiling water, turned brown. Whether this was due to enzymatic or nonenzymatic browning has not been established by this study. 


\section{Sensory analysis}

Mean values and standard deviations were obtained for the sensory scores for SDB, CDB, and FB samples (Table 4). ANOVA and LSD calculations indicate some significant differences $(p<0.05$ and $p<0.01)$ between samples (Table 5).

Color. There was no significant difference between the samples with respect to color. All samples exhibited some dark yellow color upon evaluation by the panel. Sensory scores of this attribute ranged from 1.0 to 4.5 (FB), 0 to 4.5 (CDB), and 0.5 to 5.0 SDB). Averages were $3.2,1.9$, and 2.2 , respectively.

Odor. Significant differences $(\mathrm{p}<0.01)$ were found among all the banana puree samples as a function of odor. FB had the most pleasant odor (mean value of 4.4) while SDB (1.7) had the least.

Taste. The mean scores for taste were 3.6 (FB), 2.8 (SDB), and 2.3 (CDB). There was a significant difference $(\mathrm{p}<0.05)$ between the FB and the CDB but not between the FB and the SDB or between the SDB and the CDB. Sixteen of the 18 panelists (89\%) liked (score of 2.5 or higher) the FB sample while only 8 of $18(44 \%)$ liked the CDB and 10 of 18 (56\%) liked the SDB. SDB seems to more closely resemble the FB with respect to taste than does $\mathrm{CDB}$.

Texture. The texture of the FB sample was more acceptable (score 4.2) than the CDB sample (score 3.8) which was more acceptable than the SDB sample (score 1.2). Fourteen out of $18(78 \%)$ respondents ranked the SDB sample lower than the FB and the $\mathrm{CDB}$ sample. Fifty percent of respondents ranked $\mathrm{CDB}$ somewhere between $\mathrm{FB}$ and SDB while the other 50\% ranked FB above CDB. There was no significant difference 
between FB and CDB samples. However, there was a significant difference $(p<0.01)$ between FB and SDB and between CDB and SDB. The SDB had a much more runny/thin consistency than the other two samples.

Overall acceptability. A significant difference $(p<0.01)$ was observed between FB (3.7) and CDB (2.6) and between FB and SDB (2.2). No significant difference was observed between CDB and SDB samples with respect to overall acceptability. Based on these average acceptability values, overall acceptance of the fresh banana was better than the two dried samples.

\section{Discussion}

It appears that spray drying ripe bananas to preserve their food value, and thereby preserving, in part, this valuable crop, is feasible under laboratory conditions. A high percentage of its food value is retained using this process. While it appears that the percent yield of the spray dried banana powder is less than convection dried, upon examination of percent yield based on total solids, the percent yield value for spray dried powder rises remarkably. There is a $72 \%$ recovery of solids through the spray drying process. Some losses occurred as it was hard to collect all the powder samples as some tended to stick to the sides of the drying chamber walls. Small test dryer dimensions result in closer proximity of the atomizer to the chamber walls and, as a result, more particles adhere to the walls (Masters, 1985).

The moisture content (3.58\%) of SDB powder obtained in this study is within the values reported in the literature for spray dried products such as skim milk, 3.5 to $4.0 \%$; whole milk, 3.5 to $4.5 \%$; coffee, 2.0 to $3.0 \%$; whole eggs, 3.5 to $4.5 \%$; and tomatoes, 
3.0 to $3.5 \%$ (Brennan, 1993). The higher moisture content $(9.31 \%)$ of the CDB is due to the lower oven temperature $\left(63^{\circ} \mathrm{C}\right)$ compared to the temperature at which the banana was spray dried $\left(190^{\circ} \mathrm{C}\right)$. However, this may not affect powder quality since, as a result of the $a_{w}$ examination, most of this water is bound and not available for most chemical and biological reactions. Powders from both drying methods should maintain quality during storage and handling. One might be able to reach a lower percent moisture in the CDB if it is heated longer. However, then there would be the problem of damage to the food since lower heating temperatures for a longer time cause more damage than higher heating temperatures for a short time (Park, 1996).

Agricultural Handbook No. 8 (USDA, 1982) lists the protein content of dehydrated or banana flakes as $4.01 \%$ (dry basis). Of the two drying treatments, CDB was closer (3.66\%) in achieving the composition table value. The spray dried powder only had a protein content of $1.51 \%$ (dry basis). However, the maltodextrin added to the banana puree to be spray dried accounts for almost half of the powder. So in actuality the protein content is about $3 \%$ (dry basis) while the fat and ash contents are approximately 0.3 and $3.4 \%$, respectively. These values are very similar to the results found for CDB powder and the DHYB food composition values.

Due to the high potassium content of banana pulp, researchers expected to produce potassium-rich banana powders through both drying treatments. The convection dried banana powder has a very high potassium content. In a comparison with the value from the food composition table (USDA, 1982), the powder produced from spray drying has a relatively low potassium content. While the potassium content for the SDB powder 
reported in Table 2 seems low $\left(4.58 \mathrm{mg} \mathrm{g}^{-1}\right)$, when taking into account the high maltodextrin content of the powder, the amount of potassium is approximately $9 \mathrm{mg} \mathrm{g}^{-1}$. However, this by no means compares to the $20.76 \mathrm{mg} \mathrm{g}^{-1}$ reported for the CDB powder. During the ashing process SDB powder readily foamed, due to the addition of maltodextrin, and loss occurred as a result. Further testing is warranted.

The bulk density, or the volume the powder will occupy, includes both the air between the particles and the solid particles. Most food powders have a bulk density between 0.3 and $0.8 \mathrm{~g} \mathrm{~cm}^{-3}$ (Peleg, 1983). The value obtained for SDB in the present study $\left(0.43 \mathrm{~g} \mathrm{~cm}^{-3}\right)$ is similar to the findings of Bhandari et al. (1993) in their determination of the bulk density of spray dried black current juice. Their values for bulk density ranged from 0.47 to $0.58 \mathrm{~g} \mathrm{~cm}^{-3}$. The bulk density of the $\operatorname{CDB}\left(0.84 \mathrm{~g} \mathrm{~cm}^{-3}\right)$ is greater due to the fact that its moisture content is greater and this moisture was included in the mass of the powder.

Banana powders were difficult to disperse in water. The small surface areas of the powder particles, their inability to sink instead of float, and their observed insolubility in water contributed to the clumping observed. The lack of a standardized method to analyze foud powder dispersibility may have contributed to these results. Further research examining the mixing of food powders into other ingredients, other than water, before their incorporation into food products, is warranted.

The sensory qualities of food powders have not been extensively studied. Most recent research has centered around maltodextrin additives (Bhandari et al., 1993; King, 1995), dispersibility (Al-Kahtani and Hassan, 1990; Bhandari et al., 1993), bulk density 
(Bhandari et al. 1993; Konstance et al., 1995; Onwulata et al., 1994) and flow properties (Konstance et al., 1995). However, if a food powder is going to be incorporated into a food processing scheme, sensory evaluations play a vital role in determining the acceptability of the powder. After all, the prediction of whether a food product will be accepted by consumers is a primary goal of sensory evaluation (Parolari, 1996).

With the exception of color, the purees made from $\mathrm{CDB}$ and SDB could not achieve the quality of the FB puree. Looking at mean intensity values, it seems odor and texture, rather than color and taste, most influenced overall likeness of FB over CDB and CDB over SDB. The runny texture of the SDB influenced the panelists' overall lower acceptability score of that sample. This runny texture was the result of the water added to achieve the same moisture content as fresh bananas. The lack of acceptance of the SDB sample with respect to texture is due to the preparation of the SDB puree and not necessarily to the process of spray drying or to the powder itself. It has been shown that texture is usually cited as the reason for disliking a food rather than liking it (Cardello, 1994). Since the lack of viscosity seems to be an important dimension of acceptability, future sensory evaluations should control for viscosity as part of the study.

While panelists ranked the odor of the FB puree very high, they found the odor of the two dried banana purees less pleasant. The odor of the SDB puree received a lower mean score than the $\mathrm{CDB}$ puree. In fact, one panelist described the SDB puree as having a "processed odor." There are two possibilities for this. First, odors in the air used to spray dry the banana puree may have been absorbed by the powder. Second, the metal pressure nozzle used to pump the puree into the drying chamber may have contributed 
odors that the powder absorbed. However, it is important to recognize that this sensory panel indicated no significant differences between SDB and CDB powder with respect to overall acceptability.

Since all samples were dark yellow, it is not surprising that color had little influence on overall acceptability. Banana pulp contains three major pigments, in very low concentrations, which contribute to its color. These include lutein, alpha-carotene, and beta-carotene (Shewfelt, 1986). These pigments are susceptible to both enzymatic and non-enzymatic browning. Enzymatic browning involves the oxidation of these pigments by the enzyme polyphenol oxidase. Heat destroys this enzyme and spray drying produces enough heat to destroy this enzyme. The powder produced by the spray drying process is light yellow and lacks any brown color seen in the convection dried powder. Convection drying will also destroy polyphenol oxidase eventually, but it takes time to achieve this level of heat in the product, giving this enzyme time to oxidize these pigments. This suggests that $\mathrm{CDB}$ powder, added to a food product, may affect the color of that product while SDB powder may not.

Sensory analyses were conducted on only one sample from each treatment (FB, $\mathrm{CDB}$, and SDB). The results obtained from this study need to be verified by a duplicate sensory evaluation. However, this study is useful in that it lays the groundwork for the sensory acceptability of banana powder as a food ingredient. Also, the condition of spray dried banana powder after long term storage has not been examined. This may be the next logical research step toward perfecting this powder as a food ingredient. 
Whether or not spray dried bananas can be used as an economical and effective food ingredient has not been established by this study. Nevertheless, this powder has potential for use in the food processing industry. Spray drying offers a continuous process to produce powdered products from liquid food purees. The findings of this study suggest that it is indeed feasible to spray dry ripe bananas and produce a good quality powder. While further work needs to be done with respect to sensory analysis, especially with respect to texture, there is high promise for the use of SDB powder as a food ingredient.

\section{Acknowledgement}

The authors would like to thank Cerestar USA, Inc. (Hammond, IN, USA) for supplying maltodextrin. 
Table 2. Chemical Analysis of SDB and CDB Powder and Tabulated Fresh and Dehydrated Bananas

$\underline{\text { Treatment }}$

Measurement

Proximate Analysis

Moisture(\%)

3.58

$1.46(1.51)$

9.31

$3.32(3.66)$

$0.16(0.17)$

$0.27(0.30)$

$1.60(1.72)$

$2.70(2.98)$

$93.14(96.60)$

$84.43(92.10)$

$4.42(4.58)$

$19.83(20.76)$

Potassium (mg g ${ }^{-1}$ )
Food Composition Table Values

$\mathrm{FB}^{\mathrm{b}}$

DHYB $^{\mathrm{C}}$

$$
4.42(4.58)
$$

Values in ( ) are expressed on a dry basis while all other values are expressed in wet basis.

"Source: United States Department of Agriculture (1982). Agricultural Hanabook No. 8. (S. E. Gebhardt,

R. Cutrufelli \& R. H. Matthews, Eds.). Washington D. C.: U. S. Government Printing Office.

${ }^{\mathrm{b}}$ fresh bananas

'dehydrated bananas

${ }^{d} \mathrm{CHO}=$ carbohydrates 
Table 3. Physical Properties of SDB and CDB Powders

Treatment

\begin{tabular}{lll} 
Measurement & SDB & CBD \\
\hline Bulk Density $\left(\mathrm{g} \mathrm{cm}^{-3}\right)^{\mathrm{a}}$ & 0.43 & 0.84 \\
${\text { Dispersibility }(\mathrm{m})^{\mathrm{b}}}$ & 9.75 & 4.25 \\
Water Activity $^{\mathrm{c}}$ & 0.19 & 0.21 \\
\hline
\end{tabular}

${ }^{\mathrm{a}}$ includes moisture

b $20^{\circ} \mathrm{C}_{2} \mathrm{O}$

${ }^{\circ}$ at $20^{\circ} \mathrm{C}$ 
Table 4. Mean attribute intensity ratings (and standard deviations) for sensory scores ${ }^{b}$

\begin{tabular}{|c|c|c|c|c|c|}
\hline Treatment $^{c}$ & color & odor $^{d}$ & taste $^{d}$ & texture ${ }^{d}$ & $\begin{array}{l}\text { Overall } \\
\text { acceptability }^{\dot{c}}\end{array}$ \\
\hline SDB & $2.2 \pm 1.9$ & $1.7 \pm 1.1$ & $2.8 \pm 1.4$ & $1.2 \pm 1.5$ & $2.2 \pm 1.2$ \\
\hline $\mathrm{CDB}$ & $1.9 \pm 1.3$ & $2.3 \pm 1.3$ & $2.3 \pm 1.3$ & $3.8 \pm 1.0$ & $2.6 \pm 1.3$ \\
\hline FB & $3.2 \pm 0.9$ & $4.4 \pm 0.4$ & $3.6 \pm 1.2$ & $4.2 \pm 0.6$ & $3.7 \pm 1.2$ \\
\hline
\end{tabular}

${ }^{\mathrm{a}}$ Means of 18 scores.

${ }^{b}$ Scores were based on a 5 centimeter long line scale with the following descriptors at each end: light yellow (5) and dark yellow (0) for color, pieasant (5) and unpleasant $(0)$ for odor, extreme like (5) and extreme dislike (0) for taste; smooth (5) and watery (0) for texture; and excellent (5) and poor (0) for overall acceptability.

' $\mathrm{SDB}=$ spray dried banana, $\mathrm{CDB}=$ convection dried banana, and FB = fresh banana

'Significant difference between treatments. 
Table 5. Analysis of Variance Data for Sensory Analysis Attributes

Attribute: Color

\begin{tabular}{lccccc}
\hline Source of Variation & $\begin{array}{l}\text { Degrees of } \\
\text { Freedom }\end{array}$ & $\begin{array}{l}\text { Sum of } \\
\text { Squares }\end{array}$ & $\begin{array}{l}\text { Mean } \\
\text { Square }\end{array}$ & F-ratio & Significance \\
\hline Treatment & & & & & \\
Subject $(\mathrm{n}=18)$ & 2 & 4.74 & 2.37 & 1.07 & .01 \\
Interaction & 17 & 29.63 & 1.74 & 0.78 & .01 \\
Total & 34 & 75.53 & 2.22 & & \\
\hline
\end{tabular}

Attribute: Odor

\begin{tabular}{lllrrr}
\hline Source of Variation & $\begin{array}{l}\text { Degrees of } \\
\text { Freedom }\end{array}$ & $\begin{array}{l}\text { Sum of } \\
\text { Squares }\end{array}$ & $\begin{array}{l}\text { Mean } \\
\text { Square }\end{array}$ & F-ratio & Significance \\
\hline Treatment & & & & & \\
Subject $(\mathrm{n}=18)$ & 2 & 79.47 & 35.24 & 54.22 & .01 \\
Interaction & 17 & 30.68 & 1.80 & 2.77 & .01 \\
Total & 34 & 22.00 & 0.65 & & \\
\hline
\end{tabular}

Attribute: Taste

\begin{tabular}{llllll}
\hline Source of Variation & $\begin{array}{l}\text { Degrees of } \\
\text { Freedom }\end{array}$ & $\begin{array}{l}\text { Sum of } \\
\text { Squares }\end{array}$ & $\begin{array}{l}\text { Mean } \\
\text { Square }\end{array}$ & F-ratio & Significance \\
\hline Treatment & & & & & \\
Subject $(\mathbf{n}=18)$ & 2 & 15.12 & 7.56 & 4.06 & .05 \\
Interaction & 17 & 22.88 & 1.35 & 0.73 & .01 \\
Total & 34 & 63.32 & 1.86 & & \\
\hline
\end{tabular}

Attribute: Texture

\begin{tabular}{llrrrr}
\hline Source of Variation & $\begin{array}{l}\text { Degrees of } \\
\text { Freedom }\end{array}$ & $\begin{array}{l}\text { Sum of } \\
\text { Square }\end{array}$ & $\begin{array}{l}\text { Mean } \\
\text { Square }\end{array}$ & F-ratio & Significance \\
\hline Treatment & & & & & \\
Subject $(\mathrm{n}=18)$ & 2 & 94.15 & 47.08 & 21.11 & .01 \\
Interaction & 17 & 1.19 & 0.07 & 0.04 & .05 \\
Total & 34 & 75.98 & 2.23 & & \\
\hline
\end{tabular}

Attribute: Overall Acceptability

\begin{tabular}{lccrcc}
\hline Source of Variation & $\begin{array}{l}\text { Degrees of } \\
\text { Freedom }\end{array}$ & $\begin{array}{l}\text { Sum of } \\
\text { Squares }\end{array}$ & $\begin{array}{l}\text { Mean } \\
\text { Square }\end{array}$ & F-ratio & Significance \\
\hline Treatment & & & & & \\
Subject $(\mathrm{n}=18)$ & 2 & 22.02 & 11.01 & 6.22 & .01 \\
Interaction & 17 & 18.65 & 1.10 & 0.62 & .05 \\
Total & 34 & 60.34 & 1.77 & & \\
\hline
\end{tabular}

- Treatments were spray dried, convection dried, and fresh banana 


\section{References}

Al-Kahtani, H. A. \& Hassan, B. H. (1990). Spray drying of roselle (Hibiscus sabdariffa L.) extract, Journal of Food Science, 55, 1073-1076.

Arbuckle, W. S. (1973). Dairy products. In: Quality Control for the Food Industry (edited_by A. Kramer \& B. A. Twigg). Pp. 92-156. Westport, CT: AVI Publishing Company, Inc.

Association of Official Analytical Chemists (1990). Official Methods of Analysis (15 Ed.). Arlington, VA: Authors.

Association of Official Analytical Chemists (1995). Official Methods of Analysis of $A O A C$ International ( $16^{\text {th }}$ ed.). Gathersburg, $\mathrm{MD}$ : Authors.

Bhandari, B. R., Dumoulin, E. D., Richard, H. M. J., Noleau, I. \& Lebert, A. M. (1992). Flavor encapsulation by spray drying: Application to citral and linalyl acetate, Journal of Food Science, 57, 217-221.

Bhandari, B. R. Senoussi, A., Dumoulin, E. D. \& Lebert, A. M. (1993). Spray drying of concentrated fruit juices, Drying Technology, 11, 1081-1092.

Brennan, J. G. (1993). Spray drying. In: Encyclopedia of Food Science, Food Technology and Nutrition (edited by R. Macrae, R. K. Robinson \& M.J. Sadler). Pp. 1469-1476. San Diego, CA: Academic Press.

Cano, P., Marin, M. A. \& Fuster, C. (1990). Freezing of banana slices. Influence of maturity level and thermal processing prior to freezing, Journal of Food Science, $55,1070-1072$.

Cardello, A. V. (1994). Consumer expectations and their role in food acceptance. In: Measurement of Food Preferences (edited by H. J. H. MacFie \& D. M. H. 
Thompson), Pp. 253-297. New York: Chapman and Hall.

Constidine, J. \& Constidine, G. D. (1982). Foods and Food Production Encycloyedia.

Pp.138-143, 1892-1894. New York: Van Nostrand Reinhold.

Fennema, O. (1975). Introduction to food preservation. In: Principles of Food Science

Part II: Physical Principles of Food Preservation (edited by O. Fennema). Pp.

1-8. New York: Marcel Dekker.

Forsyth, W. G. C. (1980). Banana and plantains. In: Tropical and Subtropical Fruits

(edited by S. Nagy \& P. E. Shaw). Pp. 258-278. Westport, CT: AVI Publishing Company, Inc.

Igoe, R. S. \& Hui, Y. H. (1996). Dictionary of Food Ingredients (3 ${ }^{\text {rd }}$ ed.). P. 88. New York: Chapman \& Hall.

Jayaraman, K. S. \& Das Gupta, D. K. (1992). Dehydration of fruits and vegetables:

Recent development in principles and techniques, Drying Technology, 10, 1-50.

Karel, M. (1975). Dehydration of foods. In: Principles of Food Science Part II:

Physical Principles of Food Preservation (edited by O. Fennema). Pp. 309-357. New York: Marcel Dekker.

King, C. J. (1995). Spray drying: Retention of volatile compounds revisited. Drying Technology, 13, 1221-1240.

Konstance, R. P., Onwulata, C. I. \& Holsinger, V. H. (1995). Flow properties of spraydried encapsulated butteroil. Journal of Food Science, 60, 841-844.

Marriott, J. (1980). Bananas: Physiology and biochemistry of storage and ripening for optimum quality, Critical Reviews in Food Science and Nutrition, 13(11), 4l-88.

Masters, K. (1985). Spray Drying Hondbook. Pp. 292-294. New York: John Wiley and 
Sons.

McEvily, A. J., Iyengar, R. \& Otwell, W. S. (1992). Inhibition of enzymatic browning in foods and beverages, Critical Reviews in Food Science and Nutrition, 32(3), 253273.

Onwulata, C., Smith, P. W., Craig, J. C., Jr. \& Holsinger, V. H. (1994). Physical properties of encapsulated spray-dried milk fat, Journal of Food Science, 59, $316-$ 320.

Palmer, J. K. (1971). The banana. In: The Biochemistry of Fruits and their Products (edited by A. C. Hulme). Pp. 65-105. New York: Academic Press.

Park, Y. W. (1996). Determination of moisture and ash contents in foods. In: Handbook Of Food Analysis (edited by L. M. L. Nollet). Pp. 59-92. New York: Marcel Dekker.

Parolari, G. (1996). Physical characteristics of food powders. In: Physical Properties of Foods (edited by L. M. L. Nollet). Pp. 163-196. New York: Marcel Dekker.

Peleg, M. (1983). Physical characteristics of food powders. In: Physical Properties of Foods (edited by M. Peleg \& E. B. Bagley). Pp. 293-323. Westport, CT: AVI Publishing Company, Inc.

Perkin-Elmer Corporation (1982). Analytical Methods for Atomic Absorption Spectrophotometry. P. 19. Norwalk, CT: Authors.

Shewfelt, R. L. (1986). Flavor and color of fruits as affected by processing. In: Commercial Fruit Processing (edited by J. G. Woodroff \& B. S. Luh). Pp. 481529. Westport, CT: AVT Publishing Company, Inc.

Simmonds, N. W. (1959). Bananas ( ${ }^{\text {nd }}$ ed.). Pp. 214-220. London: Longmans, Green, \& 
Co., Ltd.

United States Department of Agriculture (1982). Composition of foods. In: Agricultural Handbook No. 8 (edited by S. E. Gebhardt, R. Cutrufelli \& R. H. Matthews). Pp. 60-61. Washington D. C.: United States Government Printing Office.

Valles, J. P. (1968). The World Market for Bananas, 1964-72: Outlook for Demand, Supply, and Prices. Pp. 197-198. New York: Frederick A. Praeger. 


\section{CHAPTER 3}

\section{SUMMARY AND RECOMMENDATIONS}

\section{Summary}

Researchers are interested in the feasibility of spray drying ripe banana pulp into a powder. Bananas are a climacteric fruit, exhibit a rapid rise in respiration, and, as a result, ripen within two to five days. As a result of their short shelf life there have been efforts to preserve this fruit. Many preservation methods exist to convert perishable fresh foods into stable products with an extended shelf life. The removal of water preserves food products. It has been shown that dehydration is one of the most economical methods to preserve food products through the removal of water (Jayaraman \& Das Gupta, 1992). Spray drying may be an effective method to remove water from banana pulp to produce a fine powder that may be incorporated into other food products as a food ingredient thereby enhancing the nutritional value of those food products.

The objective of this study was to determine the chemical, physical, and sensory characteristics of spray dried banana powder produced under laboratory conditions. The evaluation phase was conducted as a comparative analysis using the convection drying method as a base line. The spray drying of liquid banana into a dry powder material may provide a finished powdered product that can be incorporated into processed food products as a nutritious food ingredient. Examples of food products include baby food, bakery items, candy, and frostings.

The proximate composition values varied widely between the two samples. Convection dried banana had a greater moisture, protein, lipid, and ash, but not 
carbohydrate, content than spray dried banana samples. The spray dried banana powder had a bulk density similar to other food powders and less than convection dried bananas. The convection dried banana powder's bulk density was greater, primarily due to a higher moister content. CDB powder was high in potassium while the SDB powder had a relatively low level of potassium due to the addition of maltodextrin. Both processes produced powders with a low $\mathrm{a}_{\mathrm{w}}$. Also, both powders did not disperse well in water due to their small particle size, the inability of the powders to sink instead of float, and the insolubility of the powders.

Sensory evaluations of the powders were also conducted. These evaluations measured color, odor, taste, texture, and overall acceptability. The taste of spray dried banana most closely matched the fresh banana while its odor and texture did not do as well compared with the convection dried sample. The results are particularly interesting and stress the need for further research. Of primary interest is the texture attribute of spray dried banana samples. The spray dried banana samples were runny and influenced the panelists' overall acceptability scores in a negative way. It has been shown that texture is usually cited as the reason for disliking food rather than liking it (Cardello, 1994). The decrease in acceptance of the spray dried banana samples with respect to texture was due to the preparation of the samples and not due to the spray drying process nor to the powder itself. Since the lack of viscosity influenced acceptability, future studies need to control for this attribute.

The feasibility of this spray drying process has been established. However, the results need to be verified by other evaluations, including duplicate sensory evaluations. 


\section{Recommendations}

Spray dried banana was only compared to convection dried banana. Many other types of drying processes exist. It may be necessary to compare SDB to drum dried bananas, for instance, to determine the level of feasibility, reliability, and reproducibility of the results.

Future analyses need to be performed to further investigate the potential of the spray dried banana powder as a food ingredient. Five primary examinations need to be performed to further evaluate the potential of spray dried banana powder in food processing. First, research examining the dispersibility of food powders, particularly spray dried banana powders, is warranted. The rehydration of the powder needs further investigation. Second, color changes, specifically the browning that occurred when the powder was mixed with water, deserves considerable attention and follow up research. Third, the evaluation of spray dried banana powder after long term storage has not been examined and these types of shelf-life studies need to be conducted. Fourth, further sensory evaluations, controlling for texture and viscosity, need to be carried out to determine the quality and application of spray dried banana powder as an effective food ingredient. Finally, ascertaining the vitamin $\mathrm{B}_{6}$ and $\mathrm{A}$ content of the powder will impact the nutritional assessment of this potential food ingredient. 


\section{References}

Abeles, F. B. (1973). Ethylene in plant biology. New York: Academic Press.

Aguilar, C. A, Hollender, R, \& Ziegler, G. R. (1994). Sensory characteristics of milk chocolate with lactose from spray-dried milk powder. Journal of Food Science, 59, 1239-1243.

Al-Kahtani, H. A, \& Hassan, B. H. (1990). Spray drying of roselle (Hibiscus sabdariffa L.) extract. Journal of Food Science, 55, 1073-1076.

Arbuckle, W. S. (1973). Dairy products. In A. Kramer \& B. A. Twigg (Eds.), Quality control for the food industry (Vol. 2, pp. 92-156). Westport, CT: AVT.

Association of Official Analytical Chemists. (1990). Official Methods of Analysis ( $15^{\text {th }}$ ed.). Arlington, VA: Authors.

Association of Official Analytical Chemists. (1995). Official Methods of Analysis of AOAC International ( $16^{\text {th }}$ ed.). Gathersburg, MD: Authors.

Bhandari, B. R., Dumoulin, E. D., Richard, H. M. J., Noleau, I., \& Lebert, A. M. (1992). Flavor encapsulation by spray drying: Application to citral and linalyl acetate. Journal of Food Science, 57, 217-221.

Bhandari, B. R., Senoussi, A., Dumoulin, E. D., \& Lebert, A. M. (1993). Spray drying of concentrated fruit juices. Drying Technology, 11, 1081-1092.

Boersen, A. C. (1990). Spray drying technology. Journal of the Society of Dairy Technology, 43, 5-7.

Brennan, J. G. (1993). Spray drying. In R. Macrae, R. K. Robinson, \& M. J. Sadler (Eds.), Encyclopedia of food science, food technology and nutrition (Vol 3, pp. 1469-1476). San Diego, CA: Academic Press.

Cano, P., Marin, M. A., \& Fuster, C. (1990). Freezing of banana slices. Influence of maturity level and thermal processing prior to freezing. Journal of Food Science, 55 , 1070-1072.

Cardello, A. V. (1994). Consumer expectations and their role in food acceptance. In H. J. H. MacFie and D. M. H. Thomson (Eds.), Measurement of food preferences (pp. 253-297). New York: Chapman \& Hall.

Chang, Y. I., Scire, J., \& Jacobs, B. (1988). Effect of particle size and microstructure properties on encapsulated orange oil. In S. J. Risch \& G. A. Reineccius 
(Eds.), Flavor encapsulation (pp. 87-102). Washington D. C.: American Chemical Society.

Constidine, D. M., \& Constidine, G. D. (Eds.) (1982). Foods and food production encyclopedia. New York: Van Nostrand Reinhold.

Desobry, S. A., Netto, F. M., \& Labuza, T. P. (1997). Comparison of spraydrying, drum drying and freeze-drying for $\beta$-carotene encapsulation and preservation. Journal of Food Science, 62, 1158-1162.

Daniells, J. (1993). Bananas and plantains. In R. Macrae, R. K. Robinson, \& M. J. Sadler (Eds.), Encyclopedia of food science, food technology and nutrition (Vol. 1, pp. 302-308). San Diego, CA: Academic Press.

Eskin, N. A. M., Henderson, H. M., \& Townsend, R. J. (1971). Biochemistry of foods. New York: Academic Press.

Fennema, O. (1975). Introduction to food preservation. In O. Fennema (Ed.), Principles of food science part II: Physical principles of food preservation (pp. 1-8). New York: Marcel Dekker.

Fennema, O. (1996). Food chemistry ( $3^{\text {rd }}$ ed.). New York: Marcel Dekker.

Food and Drug Administration, Department of Health and Human Services. (1998). Code of federal regulations. Washington D. C.: U. S. Government Printing Office.

Forsyth, W. G. C. (1980). Banana and plantains. In S. Nagy \& P. E. Shaw (Eds.), Tropical and subtropical fruits (pp. 258-278). Westport, CT: AVI.

Francis, F. J. (1983). Colorimetry in foods. In M. Peleg \& E. B. Bagley (Eds.), Physical properties of foods (pp. 105-123). Westport, CT: AVI.

Haard, N. F. (1984). Postharvest physiology and biochemistry of fruits and vegetables. Journal of Chemical Education, 61, 277-283.

Holiday, M. A. (1988). Requirements for sodium chloride and potassium and their interrelation with water requirements. In R. C. Tsang \& B. L. Nichols (Eds.), Nutrition during infancy (pp. 160-173). Philadelphia: Hanley \& Belfus.

Hui, Y. H. (Ed.). (1991). Data sourcebook for food scientists and technologists. New York: VCH Publishers. 
Igoe, R. S., \& Hui, Y. H. (1996). Dictionary of food ingredients. New York: Chapman \& Hall.

Jayaraman, K. S., \& Das Gupta, D. K. (1992). Dehydration of fruits and vegetables: Recent development in principles and techniques. Drying Technology, 10, 150.

Joslyn, M. A. (1970a). Moisture content and total solids. In M. A. Joslyn (Ed.), Methods in food analysis ( $2^{\text {nd }} \in d .$, pp. 67-108). New York: Academic Press.

Joslyn, M. A. (1970b). Extraction methods and separation processes. In M. A. Joslyn (Ed.), Methods in food analysis ( $2^{\text {nd }}$ ed., pp. 141-200). New York: Academic Press.

Karel, M. (1975). Dehydration of foods. In O. Fennema (Ed.), Principles of food science II: Physical principles of food preservation (pp. 309-357). New York: Marcel Dekker.

Kenyon, M. M., \& Anderson, R. J. (1988). Maltodextrins and low dextroseequivalence corn syrup solids. In S. J. Risch \& G. A. Reineccius (Eds.), Flavor encapsulation (pp. 7-1 1). Washington D. C.: American Chemical Society.

King, C. J. (1995). Spray drying: Retention of volatile compounds revisited. Drying Technology, 13, 1221-1240.

Konstance, R. P., Onwulata, C. I., \& Holsinger, V. H. (1995). Flow properties of spray-dried encapsulated butteroil. Journal of Food Science, 60, 841-844.

Langdon, T. T. (1987). Preventing of browning in fresh prepared potatoes without the use of sulfiting agents. Food Technology, 41(5), 64-67.

Leveille, G. A., Zabik, M. E., \& Morgan, K. J. (1983). Nutrients in foods. Cambridge, MA: The Nutrition Guild.

Lopez, A. (1987). A complete course in canning and related processes. Baltimore, MD: The Canning Trade.

Luh, B. S., Kean, C. E., \& Woodruff, J. G. (1986). Canning of fruits. In J. G. Woodruff \& B. S. Luh (Eds.), Commercial fruit processing (pp. 163-261). Westport, CT: AVI.

Malundo, T. M. M., Resurreccion, A. V. A., \& Koehler, P. E. (1992). Sensory quality performance of spray-dried coffee whitener from peanuts. Journal of Food Science, 57, 222-226. 
Marriott, J. (1980). Bananas: Physiology and biochemistry of storage and ripening for optimum quality. Critical Reviews in Food Science and Nutrition, 13(11), 41-88.

Maruniak, J. A., \& MacKay-Sim, A. (1984). The sense of smell. In J. R. Piggott (Ed.), Sensory analysis of foods (pp. 23-57). New York: Elsevier Science.

Masters, K. (1985). Spray drying handbook. New York: John Wiley \& Sons.

Mc Evily, A. J., Iyengar, R, \& Otwell, W. S. (1992). Inhibition of enzymatic browning in foods and beverages. Critical Reviews in Food Science and Nutrition, 32(3), 253-273.

Mc Williams, M. (1997). Foods: Experimental perspectives ( $3^{\text {rd }}$ ed.). Upper Saddle River, NJ: Prentice-Hall.

Meilgarrd, M., Civille, G. V., \& Carr, B. T. (1991). Sensory evaluation techniques ( $2^{\text {nd }}$ ed.). Boca Raton, FL: CRC Press.

Mennella, J. A (1998). Visions of the future in basic chemosensation research. Food Technology, 52(8), 58-61. 96.

Mermelstein, N. H. (1997). Advances in drying. Food Technology, 51(10), 95-

Mizrati, S., Berk, Z., \& Cogan, U. (1967). Isolated soybean protein as a banana spray drying aid. Cereal Science Today, 12, 322-325.

Molnar-Perl, L., \& Friedman, M. (1990). Inhibition of browning by sulfur amino acids. 3. Apples and potatoes. Journal of Agricultural Food Chemistry. 38, 1652-1656. Science.

Nelson, R. D. (1988). Dispersing powders in liquids. New York: Elsevier Reinhold.

Ockerman, H. W. (1991). Food science sourcebook. New York: Van Nostrand

Okos, M. R., Narsimhan, G., Singh, R. K., \& Weithauer, A. C. (1992). Food dehydration. In D. R. Heldman \& D. B. Lund (Eds.), Handbook of food engineering (pp. 437-562). New York: Marcell Dekker.

Onwulata, C., Smith, P. W., Craig, J. C., Jr., \& Holsinger, V. H. (1994). Physical properties of encapsulated spray dried milk fat. Journal of Food Science, $59,316-320$. 
Palmer, J. K. (1971). The banana. In A. C. Hulme (Ed.), The biochemistry of fruits and their products (Vol. 2, pp. 65-105). New York: Academic Press.

Papadakis, S. E., \& Bahu, R. E. (1992). The sticky issue of drying. Drying Technology, 10(4), 817-837.

Park, Y. W. (1996). Determination of moisture and ash contents in foods. In. L. M. L. Nollet (Ed.), Handbook of food analysis (pp. 59-92). New York: Marcel Dekker.

Parolari, G. (1996). Physical characteristics of food powders. In L. M. L. Nollet (Ed.), Physical properties of foods (pp. 163-196). New York: Marcel Dekker.

Peleg, M. (1983). Physical characteristics of food powders. In M. Peleg \& E. B. Bagley (Eds.), Physical properties of foods (pp. 293-323). Westport, CT: AVI.

Peris-Tortajada, M. (1996). Carbohydrates. In L. M. L. Nollet (Ed.), Handbook of food analysis (pp. 533-550). New York: Marcel Dekker.

Perkin-Elmer Corporation (1982). Analytical methods for atomic absorption spectrophotometry. Norwalk, CT: Authors.

Pomeranz, Y., \& Meloan, C. E. (1978). Food analysis: Theory and practice. Westport CT: AVI. Hall.

Potter, N. N., \& Hotchkiss, J. H. (1995). Food Science. New York: Chapman \&

Robinson, J. W. (1975). Atomic absorption spectroscopy ( $2^{\text {nd }}$ ed.). New York: Marcell Dekker.

Sczczesniak, A. S. (1998). Sensory texture profiling - historical and scientific perspective. Food Technology, 52(8), 54-57.

Sexton, S. (1997). Going bananas. The Ecologists, 27(3), 117-118.

Shahidi, F., \& Han, X. Q. (1993). Encapsulation of food ingredients. Critical Reviews in Food Science and Nutrition, 33, 501-547.

Shew, T-Y., \& Rosenberg, M. (1995). Microencapsulation by spray drying ethyl caprylate in whey protein and carbohydrate wall systems. Journal of Food Science, 60, 98-103. 
Shewfelt, R. L. (1986). Flavor and color of fruits as affected by processing. In J. G. Woodroff \& B. S. Luh (Eds.), Commercial fruit processing ( $2^{\text {nd }}$ ed., pp. 481-529). Westport, CT: AVI. Ltd.

Simmonds, N. W. (1959). Bananas ( $2^{\text {nd }}$ ed.). London: Longmans, Green, \& Co.,

Stein, J. (Ed.). (1975). The Random House college dictionary ( $5^{\text {th }}$ ed.). New York: Random House.

Svarovsky, L. (1987). Powder testing guide: Methods of measuring the physical properties of bulk powders. New York: Elsevier Science.

United States Department of Agriculture (1982). Composition of foods. In. S. E. Gebhardt, R. Cutrufelli, \& R. H. Matthews (Eds.), Agricultural handbook no. 8 (pp. 6061). Washington D. C.: United States Government Printing Office.

Valles, J. P. (1968). The world market for bananas, 1964-72: Outlook for demand, supply, and prices. New York: Frederick A. Praeger.

Weaver, C., \& Charley, H. (1974). Enzymatic browning of ripening bananas. Journal of Food Science, 39, 1200-1202.

Welz, B. (1985). Atomic absorption spectrometry ( $2^{\text {nd }}$ ed.). Deerfield Beach, FL: VCH Publishers. 

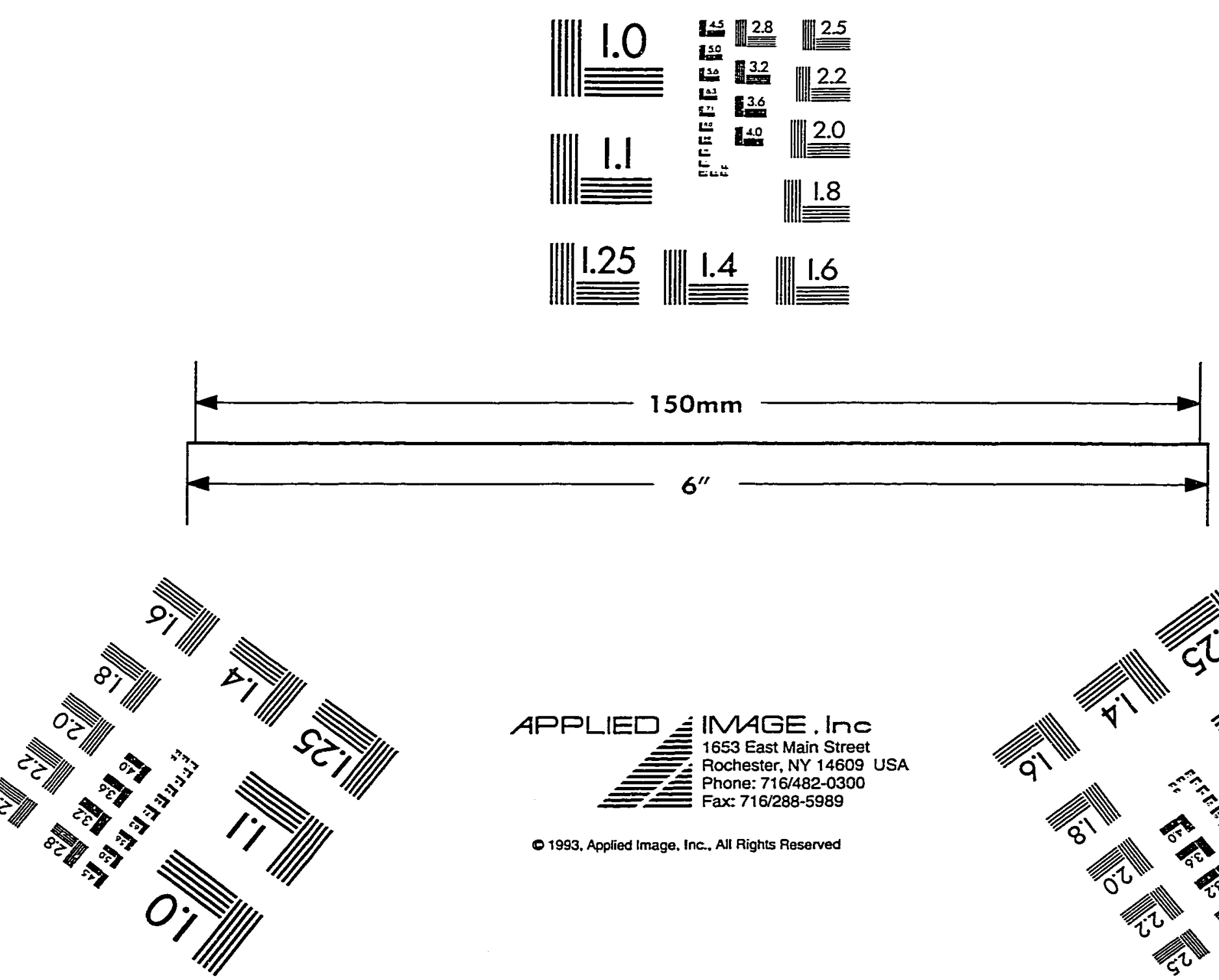

APPLIED 三 IMAGE InC 1653 East Main Street Rochester, NY 14609 USA Phone: $716 / 482-0300$ Fax: 716/288-5989

- 1993. Applied Image. Inc.. All Rights Reserved

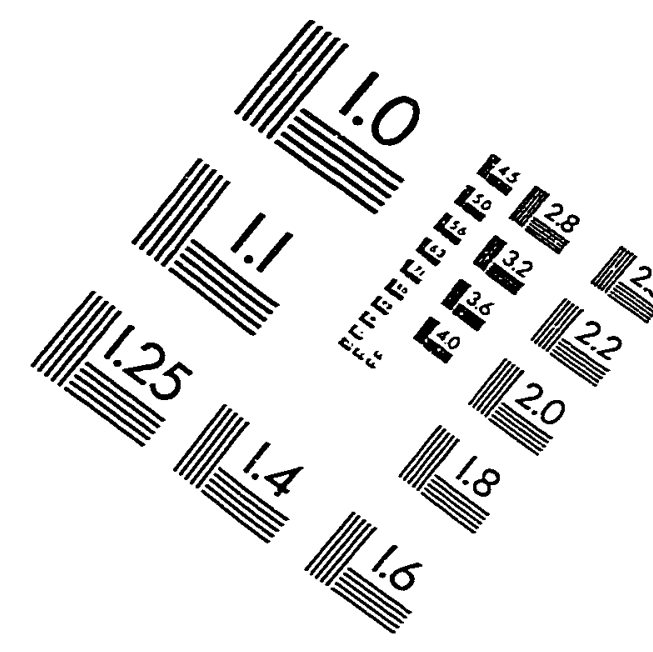

